\title{
Phenylobacterium immobile gen. nov., sp. nov., a Gram-Negative Bacterium That Degrades the Herbicide Chloridazon
}

\author{
FRANZ LINGENS, * RENATE BLECHER, HARTMUT BLECHER, FRIEDHELM BLOBEL, JÜRGEN \\ EBERSPÄCHER, CHRISTOPH FRÖHNER, HELMA GÖRISCH, HELMUT GÖRISCH, AND GERLINDE LAYH
}

Institut für Mikrobiologie der Universität Hohenheim, D 7000 Stuttgart 70, Federal Republic of Germany

\begin{abstract}
Bacteria which utilize the xenobiotic compounds chloridazon, antipyrin, and pyramidon as sole carbon sources were isolated from various soil samples. The 22 strains isolated are similar with respect to morphological, physiological, biochemical, serological, and genetic properties. These bacteria are aerobic gram-negative rods or coccal rods $(0.7$ to 1.0 by 1.0 to $2.0 \mu \mathrm{m})$ that occur singly, in pairs, or in short chains and are nonmotile and nonsporeforming. Physiological and biochemical characteristics and susceptibility to antibiotics were determined. The strains need vitamin $B_{12}$ as a growth factor; they are catalase positive and weakly oxidase positive and show slight $\mathrm{H}_{2} \mathrm{~S}$ production. All of the other tests which we performed were negative. The nutritional spectrum is extraordinarily limited, with optimal growth on chloridazon, antipyrin, pyramidon, and L-phenylalanine. Most sugars, alcohols, amino and carboxylic acids, and ordinary complex media are not utilized. The bacteria are osmotically sensitive. They are a serologically uniform group of organisms, which are harmless to rats and rabbits. Their guanine-plus-cytosine contents range between 65 and $68.5 \mathrm{~mol} \%$. The chloridazon-degrading bacteria are characterized as a new genus, Phenylobacterium, with a single species, Phenylobacterium immobile. The type strain Phenylobacterium immobile strain E (= DSM 1986), is not closely related to any other gram-negative bacterium, as shown by a $16 \mathrm{~S}$ ribosomal ribonucleic acid partial sequence analysis. This organism is a member of group I of the purple nonsulfur bacteria, but is phylogenetically isolated in this group. Phenylobacterium immobile is remotely related to Pseudomonas diminuta, Rhizobium leguminosarum, rhodopseudomonads, and Aquaspirillum itersonii. Like other members of this group, Phenylobacterium immobile contains 2,3-diamino-2,3-dideoxy-D-glucose in its lipopolysaccharide. The murein equals a normal murein from a gram-negative bacterium. All citric acid cycle enzymes are detectable in Phenylobacterium immobile.
\end{abstract}

Herbicides, fungicides, and other agrochemicals are distributed in large amounts, and microorganisms which are able to degrade synthetic organic molecules play an important role in the elimination of these chemicals from soil and water. Chloridazon [5-amino-4-chloro-2-phenyl-3(2H)pyridazinone] is the active ingredient of the herbicide Pyramin, which has been used for more than 20 years for the control of weeds in sugar beet and beet root culture. The decomposition of chloridazon (formerly called pyrazon) is a microbial process, as demonstrated by Frank and Switzer with heat-sterilized soil (17) and by the experiments of Drescher and Otto (13), who studied the breakdown of the herbicide in soil samples under various conditions. In 1969 Engvild and Jensen described the isolation of bacteria with the ability to grow on chloridazon as a sole carbon source (15). At the same time and independently, Fröhner et al. (18) isolated chloridazon-degrading bacteria with properties very similar to those of the organisms described by Engvild and Jensen. From soils from various places in the world additional chloridazon-degrading bacterial strains have been isolated (3, 28, 33; H. Blecher, Ph.D. thesis, University of Tübingen, Tübingen, Federal Republic of Germany, 1980). At the moment, 22 different isolates which can grow on the herbicide chloridazon or the structurally related analgesics antipyrin and pyramidon are known.

The chloridazon-degrading bacteria can be characterized as small rods, coccal rods, or cocci. They are aerobic, gram negative, nonmotile, nonpigmented, and nonsporeforming, and they are remarkable for their high nutritional specialization; i.e., they grow optimally on chloridazon, antipyrin (3, $38)$, pyramidon $(4)$, or L-phenylalanine $(7,42)$.

\footnotetext{
* Corresponding author.
}

None of the previous efforts to identify the chloridazondegrading bacteria have been successful. In the first attempt, Fröhner et al. tentatively identified chloridazon-degrading bacteria as Acinetobacter species, based mainly on common negative reactions for metabolic properties (18). However, the deoxyribonucleic acid (DNA), guanine-plus-cytosine $(\mathrm{G}+\mathrm{C})$ contents of the herbicide-degrading organisms $(65$ to $68.5 \mathrm{~mol} \%$ ) compared with the values of 38 to 47 mol\% for Acinetobacter strains (24) rule out a close relationship between these two groups of gram-negative bacteria. Regarding their preference for unusual carbon sources, the chloridazon-degrading bacteria exhibit a certain degree of similarity to members of the genus Pseudomonas. However, since pseudomonads are defined by motility, the nonmotile chloridazon-degrading bacteria cannot be allocated to this genus.

Recent data on the partial sequence of the $16 \mathrm{~S}$ ribosomal ribonucleic acid (rRNA) of a chloridazon-degrading bacterium have confirmed the view that these organisms represent a novel, as-yet-undescribed bacterial genus (31). Phylogenetically, the chloridazon-degrading organism is a member of group I of the purple nonsulfur bacteria, showing a remote relationship to Pseudomonas diminuta, Rhizobium leguminosarum, rhodopseudomonads, and Aquaspirillum itersonii, with binary similarity coefficients $\left(S_{\mathrm{AB}}\right.$ values) ranging between 0.51 and 0.46 .

In addition, these findings on the phylogenetic position of the chloridazon-degrading bacteria are supported by the results of studies on the lipopolysaccharide composition of this organism (43) and by serological investigations (J. Dorfer, G. Layh, J. Eberspächer, and F. Lingens, unpublished data). 
In this paper we present relevant data for the strains of Engvild and Jensen, the strains of Fröhner et al., and 16 additional bacterial strains that are able to degrade the xenobiotic compounds chloridazon, antipyrin, and pyramidon. These bacteria are classified as a new genus and species, for which the name Phenylobacterium immobile is proposed.

\section{MATERIALS AND METHODS}

Isolation of bacteria. In our laboratory isolation was achieved as described below. A $300 \mathrm{~g}$ sample of soil was mixed with $0.5 \mathrm{~g}$ of chloridazon, and the preparation was incubated at $30^{\circ} \mathrm{C}$ in a flower pot and regularly moistened with deionized water. For the isolation of antipyrin- or pyramidon-degrading bacteria these chemicals instead of chloridazon were added to the soil sample. Degradation of the xenobiotic compounds was followed by thin-layer chromatography. When decomposition was complete (usually in 1 to several weeks, depending on the soil) 5-g samples of the active soil were placed into Erlenmeyer flasks containing 50 $\mathrm{ml}$ of mineral salts medium supplemented with the carbon source required at a concentration of $0.4 \%$. This culture was incubated on a rotary shaker at $30^{\circ} \mathrm{C}$, and degradation was monitored by thin-layer chromatography. The mixed culture which developed in this culture fluid was subcultured (inoculum, $1 \%$ ) when the breakdown of the xenobiotic compound was complete. After several transfers a sample of the liquid culture was streaked onto agar plates containing the same medium. Single colonies, which normally appeared after 10 days to 3 weeks, were picked and again streaked onto agar. Usually after 5 to 10 transfers pure cultures were obtained. The isolation of strains $\mathrm{N}$ and $\mathrm{C}_{2}$ proved to be more difficult, since both of these chloridazon-degrading organisms were closely associated with other bacteria. In the case of strain $\mathrm{C}_{2}$ the other bacterium was identified as Pseudomonas cepacia.

Media. Two mineral salts media, minimal media A and B, were used. In the first years of study the organisms were cultured with minimal medium A (18). Minimal medium B, with a higher buffer capacity, was developed (37) because when chloridazon-degrading bacteria are grown on chloridazon or antipyrin, they acidify the culture fluid. Minimal medium A contains (per $1,000 \mathrm{ml}$ of deionized water) $0.875 \mathrm{~g}$ of $\mathrm{KH}_{2} \mathrm{PO}_{4}, 0.125 \mathrm{~g}$ of $\mathrm{K}_{2} \mathrm{HPO}_{4}, 0.5 \mathrm{~g}$ of $\mathrm{MgSO}_{4} \cdot 7 \mathrm{H}_{2} \mathrm{O}, 0.1$ $\mathrm{g}$ of $\mathrm{NaCl}, 0.1 \mathrm{~g}$ of $\mathrm{CaCl}_{2} \cdot 6 \mathrm{H}_{2} \mathrm{O}, 1.0 \mathrm{~g}$ of $\left(\mathrm{NH}_{4}\right)_{2} \mathrm{SO}_{4}$, and the following sources of trace elements (supplied from a stock solution): $0.5 \mathrm{mg}$ of $\mathrm{H}_{3} \mathrm{BO}_{3}, 0.04 \mathrm{mg}$ of $\mathrm{CuSO}_{4} \cdot 5 \mathrm{H}_{2} \mathrm{O}$, $0.1 \mathrm{mg}$ of $\mathrm{KI}, 0.2 \mathrm{mg}$ of $\mathrm{FeCl}_{3} \cdot 6 \mathrm{H}_{2} \mathrm{O}, 0.4 \mathrm{mg}$ of $\mathrm{MnSO}_{4} \cdot 4 \mathrm{H}_{2} \mathrm{O}, 0.4 \mathrm{mg}$ of $\mathrm{ZnSO}_{4} \cdot 7 \mathrm{H}_{2} \mathrm{O}, 0.2 \mathrm{mg}$ of $\left(\mathrm{NH}_{4}\right)_{6} \mathrm{Mo}_{7} \mathrm{O}_{24} \cdot 4 \mathrm{H}_{2} \mathrm{O}, 0.1 \mathrm{mg}$ of biotin, and $0.03 \mathrm{mg}$ of vitamin $\mathrm{B}_{12}$. The $\mathrm{pH}$ value of this medium was adjusted to 6.8 to 7.0 by adding $1 \mathrm{~N} \mathrm{NaOH}$. Minimal medium $\mathrm{B}$ contains (per $1,000 \mathrm{ml}$ of deionized water) $0.3 \mathrm{~g}$ of $\mathrm{KH}_{2} \mathrm{PO}_{4}, 0.7 \mathrm{~g}$ of $\mathrm{Na}_{2} \mathrm{HPO}_{4} \cdot 12 \mathrm{H}_{2} \mathrm{O}, 0.3 \mathrm{~g}$ of $\left(\mathrm{NH}_{4}\right) \mathrm{H}_{2} \mathrm{PO}_{4}, 0.7 \mathrm{~g}$ of $\left(\mathrm{NH}_{4}\right)_{2} \mathrm{HPO}_{4}, 0.1 \mathrm{~g}$ of $\left(\mathrm{NH}_{4}\right)_{2} \mathrm{SO}_{4}, 0.05 \mathrm{~g}$ of $\mathrm{CaCl}_{2} \cdot 6 \mathrm{H}_{2} \mathrm{O}$, $0.25 \mathrm{~g}$ of $\mathrm{MgSO}_{4} \cdot 7 \mathrm{H}_{2} \mathrm{O}$, and the same trace elements as minimal medium $\mathrm{A}$. The $\mathrm{pH}$ value of minimal medium $\mathrm{B}$ is 7.0. The minimal media were supplemented with the required carbon sources at concentrations of 0.04 to $0.1 \%$.

Complex medium A contains (per $1,000 \mathrm{ml}$ of deionized water) $5 \mathrm{~g}$ of yeast extract, $10 \mathrm{~g}$ of nutrient broth (dehydrated), and $5 \mathrm{~g}$ of $\mathrm{NaCl}$. Complex medium B contains (per $1,000 \mathrm{ml}$ of deionized water) $1 \mathrm{~g}$ of yeast extract and $1 \mathrm{~g}$ of peptone (both from Difco Laboratories, Detroit, Mich.). Medium $C$ is an enriched mineral salts medium and contains (per $1,000 \mathrm{ml}$ of minimal medium A) $1 \mathrm{~g}$ of yeast extract (Difco), $1 \mathrm{~g}$ of peptone (Difco), and $0.5 \mathrm{~g}$ of chloridazon or antipyrin. Complex medium D contains (per $1,000 \mathrm{ml}$ of deionized water) $2.5 \mathrm{~g}$ of yeast extract (Difco), $2.5 \mathrm{~g}$ of peptone (Difco), $1.5 \mathrm{~g}$ of meat extract, $2.5 \mathrm{~g}$ of $\mathrm{NaCl}$, and 1 $\mathrm{g}$ of chloridazon or antipyrin.

Agar cultures were prepared with $1.5 \%$ Bacto-Agar (Difco). Media were sterilized at $121^{\circ} \mathrm{C}$ for $20 \mathrm{~min}$, and heat-labile compounds were added by sterile filtration.

Chemicals. Chloridazon and chloridazon analogs, which were used in growth tests, were a gift from BASF, Ludwigshafen, Federal Republic of Germany. The crude product of chloridazon was purified by repeated washing with acetone. Antipyrin was purchased from Riedel de Haen, Seelze-Hannover, Federal Republic of Germany.

Proteinase $\mathrm{K}$, pronase, adenosine triphosphate, adenosine diphosphate, adenosine monophosphate, nicotinamide adenine dinucleotide, reduced nicotinamide adenine dinucleotide (NADH), nicotinamide adenine dinucleotide phosphate, reduced nicotinamide adenine dinucleotide phosphate, and coenzyme A were obtained from Boehringer, Mannheim, Federal Republic of Germany. Lysozyme, pancreatic ribonuclease, and lauroylsarcosine were obtained from Serva, Heidelberg, Federal Republic of Germany. Cesium chloride was obtained from Roth, Karlsruhe, Federal Republic of Germany, and ${ }^{3} \mathrm{H}$-labeled adenine was obtained from Amersham Buchler, Braunschweig, Federal Republic of Germany. The Sephadex G-25 used was from Pharmacia, Uppsala, Sweden. API 20E test systems were obtained from apibio Merieux, Nürtingen, Federal Republic of Germany.

Maintenance of strains. The isolated bacteria were regularly transferred as agar cultures at intervals of 2 weeks. The purity of the strains was tested at each transfer. Seven strains were stored at the Deutsche Sammlung für Mikroorganismen, Göttingen, Federal Republic of Germany (see Table 1).

Purity of cultures. None of the chloridazon-degrading bacterial strains grew on complex medium A; thus, growth on complex medium A plates indicated contamination of the culture. Purity was also checked by light microscopic examination of the bacterial cultures.

Physiological tests. The physiological tests were performed for all 22 isolates. The incubation temperature used throughout was $30^{\circ} \mathrm{C}$. The nutritional specialization and osmotic sensitivity of the strains did not allow the use of routine media. Therefore, special media on which the bacteria were able to multiply were used.

For catalase and oxidase tests the strains were cultivated on agar plates containing minimal medium B supplemented with chloridazon or antipyrin and on agar plates containing complex medium B. After 7 days of incubation, catalase activity was determined by dropping an $\mathrm{H}_{2} \mathrm{O}_{2}$ solution $(3 \%)$ onto the colonies. Oxidase activity was tested after 5 and 20 days of cultivation on agar plates by using a reagent consisting of solution A [1\% naphthol-(1) in 96\% ethanol] and solution $\mathrm{B} \quad\left(1 \% \quad N, N, N^{\prime}, N^{\prime}\right.$-tetramethyl-1,4-phenylenediamine dichloride in deionized water); 2 parts of solution $A$ and 3 parts of solution B were mixed and then immediately dropped onto the colonies.

The urease reaction was tested on agar plates containing medium $\mathrm{C}$ supplemented with $12 \mathrm{mg}$ of phenol red per liter. The concentration of $\left(\mathrm{NH}_{4}\right)_{2} \mathrm{SO}_{4}$ in medium $\mathrm{C}$ was reduced to $0.01 \%$, and $0.1 \%$ urea was added after sterilization. Arginine decarboxylase, lysine decarboxylase, and ornithine decarboxylase activities were tested on agar plates containing minimal medium B supplemented with $1.0 \mathrm{~g}$ of antipyrin 
per liter, $1.0 \mathrm{~g}$ of the required amino acid per liter, and $20 \mathrm{mg}$ of bromothymol blue per liter ( $\mathrm{pH} 7.0)$.

Fermentation reactions were tested by using the API $20 \mathrm{E}$ system, microtubes containing different carbohydrates, and phenol red as the indicator. The bacteria were suspended in medium $\mathrm{C}$, which for this purpose was adjusted to $\mathrm{pH} 7.4$. Medium $\mathrm{C}$ per se becomes neither alkaline nor acidic during growth.

Voges-Proskauer and methyl red tests were performed in tubes containing minimal medium B supplemented with $1.0 \mathrm{~g}$ of yeast extract per liter, $1.0 \mathrm{~g}$ of peptone per liter, and $2.0 \mathrm{~g}$ of glucose per liter ( $\mathrm{pH} 7.0$ ). For the Voges-Proskauer reaction $0.6 \mathrm{ml}$ of $5 \%$ naphthol-(1) in $96 \%$ ethanol and $0.2 \mathrm{ml}$ of a $40 \% \mathrm{KOH}$ solution in water were added to $1 \mathrm{ml}$ of the culture.

The indole reaction was tested in flasks containing minimal medium B supplemented with $0.5 \mathrm{~g}$ of antipyrin per liter, $0.5 \mathrm{~g}$ of yeast extract per liter, $0.5 \mathrm{~g}$ of peptone per liter, and $0.5 \mathrm{~g}$ of tryptophan per liter. The test reagent was $p$-dimethylaminobenzaldehyde $(5.0 \mathrm{~g})$ in a solution containing $75 \mathrm{ml}$ of amylalcohol and $25 \mathrm{ml}$ of concentrated $\mathrm{HCl}$.

$\mathrm{H}_{2} \mathrm{~S}$ formation was tested on agar plates containing medium $\mathrm{C}$ supplemented with $\left(\mathrm{NH}_{4}\right) \mathrm{Fe}$ (III) citrate and either $2.0 \mathrm{~g}$ of $\mathrm{Na}_{2} \mathrm{~S}_{2} \mathrm{O}_{3}$ per liter or $2.0 \mathrm{~g}$ of $\mathrm{L}$-cysteine per liter.

The formation of nitrite from nitrate was tested in tubes containing medium $\mathrm{C}$ supplemented with $1.0 \mathrm{~g}$ of $\mathrm{NaNO}_{3}$ per liter; $\left(\mathrm{NH}_{4}\right)_{2} \mathrm{SO}_{4}$ was omitted. The test reagents used were $0.5 \mathrm{~g}$ of sulfanilic acid in $15 \mathrm{ml}$ of $5 \mathrm{~N}$ acetic acid and $0.1 \mathrm{~g}$ of $\alpha$-naphthylamine dissolved in $20 \mathrm{ml}$ of boiling water to which $130 \mathrm{ml}$ of $5 \mathrm{~N}$ acetic acid was added. The occurrence of fluorescent pigments was tested on agar plates containing modified King medium B $(1.0 \mathrm{~g}$ of yeast extract, $1.0 \mathrm{~g}$ of peptone, $1.0 \mathrm{~g}$ of glycerol, $1.0 \mathrm{~g}$ of $\mathrm{MgSO}_{4} \cdot 7 \mathrm{H}_{2} \mathrm{O}$, and $1.8 \mathrm{~g}$ of $\mathrm{K}_{3} \mathrm{PO}_{4} \cdot 7 \mathrm{H}_{2} \mathrm{O}$ in 1 liter of deionized water). The $\mathrm{pH}$ value was adjusted to 7.5 .

Gelatin hydrolysis was tested in gelatin stabs containing medium $\mathrm{C}$ supplemented with $12 \%$ gelatin.

Starch hydrolysis was tested on agar plates containing medium $\mathrm{C}$ supplemented with $0.5 \mathrm{~g}$ of starch per liter. After 3 weeks of cultivation, the dishes were flooded with iodine solution and examined for clearing zones.

Esculin hydrolysis was tested on agar plates containing minimal medium B supplemented with $0.5 \mathrm{~g}$ of antipyrin per liter, $0.5 \mathrm{~g}$ of yeast extract per liter, $0.5 \mathrm{~g}$ of peptone per liter, and $1.0 \mathrm{~g}$ of $\left(\mathrm{NH}_{4}\right) \mathrm{Fe}(\mathrm{III})$ citrate per liter ( $\left.\mathrm{pH} 7.0\right)$. Esculin $(0.1 \%)$ was added after sterilization.

Cellulose hydrolysis was tested in tubes containing medium $\mathrm{C}$ and filter paper strips rising above the culture liquid. The tubes were observed for 12 weeks.

Casein hydrolysis was tested on agar plates containing medium $C$ supplemented with $0.2 \%$ casein. After 4 weeks of incubation the dishes were flooded with $20 \%$ acetic acid and examined for clearing zones.

Growth tests. The growth of chloridazon-degrading bacteria on different carbon sources was tested either on agar plates containing minimal medium A supplemented with the compound being tested at a concentration of $0.05 \%$ or in liquid cultures in $100-\mathrm{ml}$ Erlenmeyer flasks containing $50 \mathrm{ml}$ of minimal medium B supplemented with the carbon source at a concentration of 0.1 or $0.04 \%$. Agar plates were inoculated with a loopful of chloridazon-degrading bacteria suspended in saline, and incubation was for 5 weeks. Liquid cultures were inoculated with $0.5 \mathrm{ml}$ from a logarithmic culture of chloridazon-degrading bacteria in minimal medium B supplemented with either $0.1 \%$ chloridazon, $0.1 \%$ antipyrin, or $0.1 \%$ L-phenylalanine as the carbon source.
Erlenmeyer flasks were shaken at $30^{\circ} \mathrm{C}$, and growth was followed turbidimetrically. For determinations of doubling times and cell yields, cell numbers were evaluated microscopically with a cytometer chamber.

Antibiotic susceptibility. The bacteria were plated onto agar plates containing minimal medium B supplemented with chloridazon or antipyrin. The plates were incubated at $30^{\circ} \mathrm{C}$ for $20 \mathrm{~h}$, and then disks and multodisks (Oxoid Ltd., London, England) containing the amount of antibiotic desired were placed onto the agar surfaces. After incubation for 3 days at $30^{\circ} \mathrm{C}$, inhibition zones were measured.

Determination of DNA G $+\mathbf{C}$ contents. Using the method of Flossdorf (16), we subjected a total of $2.5 \times 10^{7}$ cells from a chloridazon-degrading strain together with the same number of Escherichia coli cells (for reference DNA) to lysis at $56^{\circ} \mathrm{C}$ for $10 \mathrm{~min}$ with $\mathrm{N}$-lauroyl sarcosine and ethylenediaminetetraacetate in citrate buffer $(\mathrm{pH} 7.0)$. Then the protein was digested by proteinase $\mathrm{K}$ treatment at $56^{\circ} \mathrm{C}$ for $1 \mathrm{~h}$. The lysate was mixed with a $58.1 \%$ cesium chloride solution and centrifuged at $44,000 \mathrm{rpm}$ and $25^{\circ} \mathrm{C}$ for $24 \mathrm{~h}$ in an analytical ultracentrifuge (model E; Beckman Instruments, Munich, Federal Republic of Germany) equipped with a type An-FTi rotor.

Isolation of DNA and hybridization experiments. Bacteria $(2 \mathrm{~g})$ grown in minimal medium B containing antipyrin or chloridazon were suspended in $75 \mathrm{ml}$ of $0.1 \mathrm{M}$ tris(hydroxymethyl)aminomethane hydrochloride buffer ( $\mathrm{pH}$ 7.0). Lysozyme $60 \mathrm{mg}$ in $5 \mathrm{ml}$ of tris(hydroxymethyl)aminomethane hydrochloride buffer] and $10 \mathrm{ml}$ of $0.25 \mathrm{M}$ ethylenediaminetetraacetate ( $\mathrm{pH} 8.0$ ) were added, and the suspension was incubated at $37^{\circ} \mathrm{C}$ for $15 \mathrm{~min}$, cooled in an ice bath, and treated with $0.5 \mathrm{~g}$ of sodium dodecyl sulfate in $10 \mathrm{ml}$ of tris(hydroxymethyl)aminomethane hydrochloride buffer. The cell lysate, together with $60 \mathrm{ml}$ of chloroform and $120 \mathrm{ml}$ of phenol solution, was shaken for $45 \mathrm{~min}$ at $30^{\circ} \mathrm{C}$. To prepare the phenol solution freshly distilled phenol was saturated with $0.03 \mathrm{M}$ tris(hydroxymethyl)aminomethane- $0.005 \mathrm{M}$ ethylenediaminetetraacetate- $0.05 \mathrm{M} \mathrm{NaCl}(\mathrm{pH}$ 8.0). After shaking, the aqueous layer was separated by centrifugation, and 3 parts of $96 \%$ ethanol was added. The precipitated DNA was collected with a glass rod. The isolated DNA was dissolved in sodium citrate buffer $(0.015$ $\mathrm{M}$ sodium citrate, $0.15 \mathrm{M} \mathrm{NaCl}, \mathrm{pH} \mathrm{7.0)}$ and treated with 5 $\mathrm{mg}$ of pancreatic ribonuclease per mg of DNA. The DNA concentration was determined by the method of Burton (8). Finally, the solution was again deproteinized with phenolchloroform. The DNA was precipitated with ethanol and dissolved in citrate buffer. For hybridization experiments the DNA was concentrated in a cesium chloride gradient. Hybridization was performed by the membrane filter method, as described by Denhardt (11) and Goebel and Schrempf (20). For DNA labeling bacteria were grown in minimal medium B containing antipyrin or chloridazon, and during the exponential growth phase $\left[{ }^{3} \mathrm{H}\right]$ adenine $(0.1 \mathrm{mCi})$ was added.

Isolation and analysis of murein. Murein was isolated by the method of Braun and Sieglin (9). Frozen cells were thawed and broken by shaking with glass beads. The cell envelopes obtained after differential centrifugation were treated by boiling in $4 \%$ sodium dodecyl sulfate, followed by pronase treatment. For amino acid analyses, the samples were hydrolyzed in $4 \mathrm{~N} \mathrm{HCl}$ for $15 \mathrm{~h}$ at $100^{\circ} \mathrm{C}$ and analyzed with a Unichrom amino acid analyzer containing a long column packed with type M82 resin (Beckman Instruments). Under these conditions muramic acid is well separated from glutamic acid without a temperature change. For lysozyme 
TABLE 1. Strains of chloridazon-degrading bacteria (Phenylobacterium immobile)

\begin{tabular}{|c|c|c|c|c|c|}
\hline $\begin{array}{c}\text { Strain (laboratory } \\
\text { designation) }\end{array}$ & $\begin{array}{c}\text { Carbon source for } \\
\text { enrichment }\end{array}$ & Isolated from soil of: & Reference & $\begin{array}{c}\text { Year of } \\
\text { isolation }\end{array}$ & DSM no. ${ }^{\pi}$ \\
\hline $\mathrm{J}_{1}$ & Chloridazon & Lyngby, Denmark & 15 & 1969 & 2116 \\
\hline $\mathrm{J}_{2}$ & Chloridazon & Lyngby, Denmark & 15 & 1969 & \\
\hline $\mathrm{E}^{\mathrm{T}}$ & Chloridazon & Ecuador & 18 & 1970 & 1986 \\
\hline $\mathbf{L}$ & Chloridazon & Limburgerhof, Germany & 18 & 1970 & \\
\hline $\mathrm{R}$ & Chloridazon & Rothschwaige, Germany & 18 & 1970 & \\
\hline $\mathrm{N}$ & Chloridazon & Lincoln, Nebr. & 7 & 1974 & 2113 \\
\hline $\mathrm{K}_{2}$ & Chloridazon & Eldoret-Nakaru, Kenya & 28 & 1976 & 2117 \\
\hline $\mathrm{K}_{3}$ & Chloridazon & Eldoret-Nakaru, Kenya & 28 & 1976 & \\
\hline $\mathrm{K}_{5}$ & Chloridazon & Naivasha, Kenya & 28 & 1977 & \\
\hline$Z_{5}$ & Chloridazon & Hohenheim, Germany & Blecher $^{b}$ & 1976 & \\
\hline$Z_{6}$ & Chloridazon & Hohenheim, Germany & Blecher & 1976 & 2114 \\
\hline $\mathrm{Z}_{7}$ & Chloridazon & Hohenheim, Germany & Blecher & 1976 & \\
\hline $\mathrm{Z}_{8}$ & Chloridazon & Hohenheim, Germany & Blecher & 1976 & \\
\hline$A_{6}$ & Antipyrin & Hohenheim, Germany & 3 & 1978 & \\
\hline$A_{11}$ & Antipyrin & Bad Wimpfen, Germany & 3 & 1978 & \\
\hline$A_{12}$ & Antipyrin & Bad Wimpfen, Germany & 3 & 1978 & 2115 \\
\hline$A_{13}$ & Antipyrin & Bad Wimpfen, Germany & 3 & 1978 & \\
\hline $\mathrm{A}_{14}$ & Antipyrin & Hohenheim, Germany & 3 & 1978 & \\
\hline $\mathbf{M}_{11}$ & Pyramidon & Bad Wimpfen, Germany & Blecher & 1977 & \\
\hline $\mathbf{M}_{13}$ & Pyramidon & Bad Wimpfen, Germany & 4 & 1977 & \\
\hline $\mathbf{M}_{15}$ & Pyramidon & Hohenheim, Germany & 4 & 1977 & \\
\hline $\mathrm{C}_{2}$ & Chloridazon & Cardwell, Australia & 33 & 1982 & \\
\hline
\end{tabular}

a DSM, Deutsche Sammlung für Mikroorganismen.

${ }^{b}$ H. Blecher, Ph.D. thesis.

digestion murein (about $2 \mathrm{mg} / \mathrm{ml}$ ) was shaken in $0.1 \mathrm{M}$ ammonium acetate buffer supplemented with $75 \mu \mathrm{g}$ of lysozyme per $\mathrm{ml}$ for $15 \mathrm{~h}$ at $37^{\circ} \mathrm{C}$. To remove undegraded murein, the mixture was centrifugated for $1 \mathrm{~h}$ at $40,000 \times g$. The supernatant was concentrated in a rotary evaporator and applied to a Sephadex G-25 column for the removal of lysozyme. Fractions containing the muropeptides were identified by thin-layer chromatography on cellulose plates (E. Merck AG, Darmstadt, Federal Republic of Germany), using the following solvent system: 1-butanol-acetic acidwater (4:1:5, vol/vol; upper phase).

Citric acid cycle enzymes. A cell-free extract of chloridazondegrading bacterial strain $\mathrm{E}^{\mathrm{T}}(\mathrm{T}=$ type strain) was prepared by grinding $3 \mathrm{~g}$ of deep-frozen cells with $4.5 \mathrm{~g}$ of alumina powder (Alcoa type 305) in a cold mortar. The resulting viscous mixture was taken up in $6 \mathrm{ml}$ of $0.01 \mathrm{M}$ potassium phosphate buffer ( $\mathrm{pH} \mathrm{7.0)}$ and centrifuged for $20 \mathrm{~min}$ at $20,000 \times g$. The supernatant was used as a crude extract; this crude extract was used for most tests. For molecular weight determinations and for kinetic studies the crude extract was partially purified by fractionated ammonium sulfate precipitation. The activities of the citric acid cycle enzymes were tested by previously described methods (30).

\section{RESULTS}

Isolation of strains. Since 196922 bacterial strains have been isolated by using the xenobiotic compounds chloridazon, antipyrin, and pyramidon as sole carbon sources. These bacteria were isolated from all over the world. The isolation procedure was performed at $30^{\circ} \mathrm{C}$. Most soil samples have never been treated with the herbicide chloridazon before they were incubated in the laboratory. All of the chloridazon-degrading bacterial strains are listed in Table 1.

Attempts to isolate microorganisms which degrade chloridazon or antipyrin under anaerobic conditions have not been successful (B. Schink and N. Pfennig unpublished data; E. Keller, unpublished data). All efforts to isolate chloridazon-degrading bacteria which grow at $37^{\circ} \mathrm{C}$ have also failed. For this purpose soil and water samples originating from hot springs, from near-volcanic regions, and from regions with tropical climates were subjected to chloridazon enrichment.

Morphology. (i) Colonies. The chloridazon-degrading bacteria show optimal growth on agar plates containing minimal media and chloridazon, antipyrin, or L-phenylalanine as the only carbon source. With incubation of $30^{\circ} \mathrm{C}$, single colonies are not visible before 1 week, and after 3 weeks the colonies are 1 to $2 \mathrm{~mm}$ in diameter, circular with entire edges, slightly raised, and not adherent to the agar. The colonies of strains $\mathrm{K}_{2}, \mathrm{~K}_{3}, \mathrm{~K}_{5}, \mathrm{~J}_{1}, \mathrm{~J}_{2}, \mathrm{~L}, \mathrm{M}_{11}, \mathrm{~N}, \mathrm{R}$, and $\mathrm{A}_{12}$ are smooth and shiny and can readily be emulsified in saline or water; all other strains have rough and dry colonies which cannot be emulsified in saline, where clumping occurs. In water after vigorous agitation emulsification is possible.

(ii) Cells. The chloridazon-degrading bacteria are rods, coccal rods, or cocci $(0.7$ to 1.0 by 1.0 to $2.0 \mu \mathrm{m})$ and occur singly, in pairs, in short chains, or in clumps. The cells of all strains are nonmotile, nonpigmented, and nonsporeforming and do not produce sheaths or prosthecae.

Strains $A_{6}, A_{11}, A_{13}, A_{14}, E^{T}, M_{13}, M_{15}, Z_{5}, Z_{6}$, and $Z_{7}$ form exclusively coccal rods, which tend to clump, and in liquid cultures growth is sometimes flocculent. All other strains have short rod-shaped cells which occur singly, in pairs, or in short chains. These strains never clump in liquid cultures. For the most part chains are found in cultures of strains which form smooth colonies on agar plates (strains $\mathrm{K}_{2}, \mathrm{~K}_{3}, \mathrm{~K}_{5}, \mathrm{~J}_{1}, \mathrm{~J}_{2}, \mathrm{~L}$, and $\mathrm{M}_{11}$ ). Figure 1 shows phase-contrast photomicrographs of strains $\mathrm{E}^{\mathrm{T}}, \mathrm{K}_{2}, \mathrm{~N}$, and $\mathrm{A}_{13}$.

In old cultures, especially if the bacteria are cultivated in medium D, which allows only poor growth, pleomorphic forms such as long rods ( 1.0 by 2.0 to $4.0 \mu \mathrm{m}$ ), long chains (10 to $50 \mu \mathrm{m}$ ) of cells connected by small filaments, or club-shaped and elliptical forms, may occur.

Gram staining, Ziehl-Neelsen staining, and capsule staining are negative. Electron microscopy of thin sections of chloridazon-degrading bacteria also reveals the typical gram- 

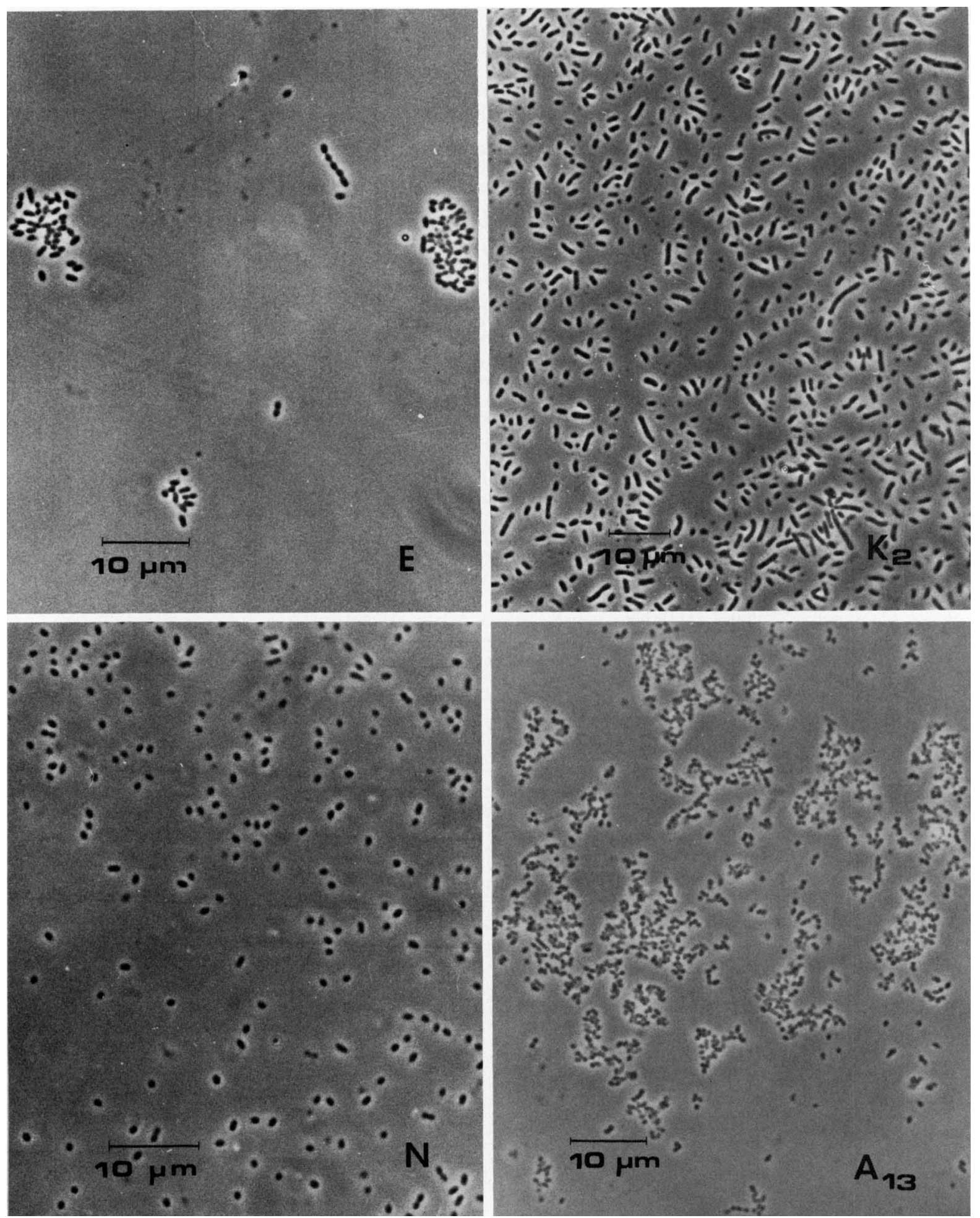

FIG. 1. Phase-contrast photomicrographs of Phenylobacterium immobile strains $\mathrm{E}^{\mathrm{T}}, \mathrm{K}_{2}, \mathrm{~N}$, and $\mathrm{A}_{13}$.

negative cell wall pattern (Fig. 2). Figure 3 shows thin sections of ruthenium red-treated bacteria, which reveal the presence of a microcapsule surrounded by a slime layer of acid polysaccharides for strain $\mathrm{K}_{2}$, one of the strains which form smooth colonies. Following the definition of Costerton et al. (10), the chloridazon-degrading bacteria possess a "flexible" capsule, which can be made visible only by electron microscopy, but no "rigid" capsule, which represents the typical Indian ink-excluding capsule type.

Physiological and biochemical characteristics. The chloridazon-degrading bacteria are aerobic with respiratory (never fermentative) metabolism. The temperature for optimum 


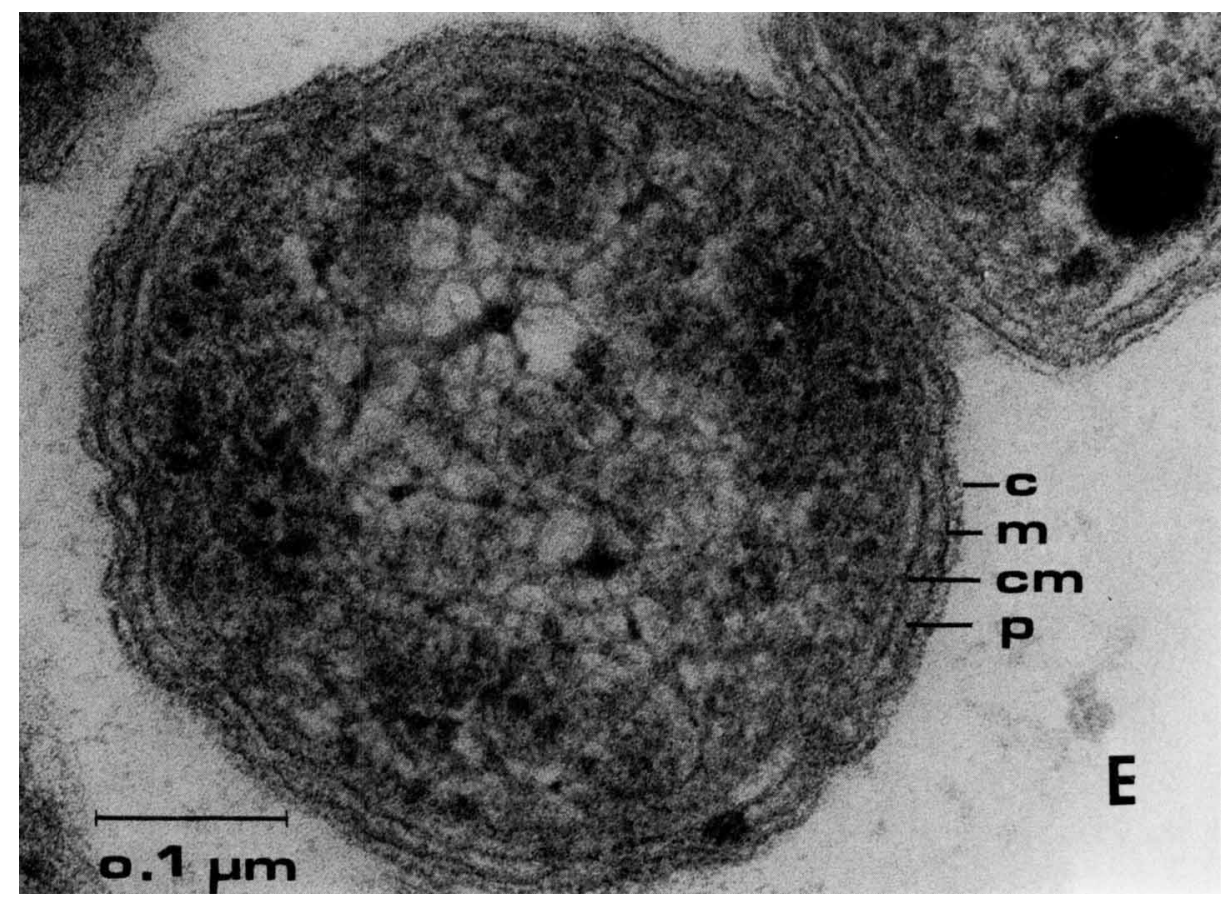

FIG. 2. Ultrathin section of a cell from Phenylobacterium immobile type strain E (= DSM 1986). $\mathrm{cm}$, Cytoplasmic membrane; $\mathrm{p}$, periplasm; $m$, outer membrane; $c$, capsule (flexible capsule).

growth is 28 to $30^{\circ} \mathrm{C}$. The strains do not grow at 4 and $37^{\circ} \mathrm{C}$. At $37^{\circ} \mathrm{C}$ the bacteria die within a few days. Growth occurs between $\mathrm{pH} 6.5$ and 8.0 ; no growth occurs at $\mathrm{pH} 4.0$ and 9.0 . Growth is optimal between $\mathrm{pH} 6.8$ and 7.0. Minimal medium A containing chloridazon, antipyrin, or pyramidon becomes acidic ( $\mathrm{pH} 6$ in the stationary phase); complex medium $\mathrm{B}$ becomes alkaline $(\mathrm{pH} 8.2)$. Vitamin $\mathrm{B}_{12}$ is required as a growth factor.

All strains produce a greenish-yellow nonfluorescent pigment in liquid media supplemented with chloridazon or antipyrin. In liquid cultures containing L-phenylalanine as the sole carbon source a yellowish-green fluorescent pigment is formed. When L-phenylalanine is added in concentrations of 3 to $5 \mathrm{~g} /$ liter, the yield of the fluorescent pigment increases. Strain $C_{2}$ is the only strain to form dark brown colonies on agar plates together with dark coloration of the surrounding agar, especially in L-phenylalanine-containing cultures.

The nutritional specialization and osmotic sensitivity of the herbicide-degrading bacteria did not allow use of routine media for biochemical characterization. Therefore, the tests were performed in special media, as described above. The biochemical characteristics, which were determined for all strains, and the physiological characteristics are as follows: strictly anaerobic; metabolism respiratory, never fermentative; optimum temperature for growth, 28 to $30^{\circ} \mathrm{C}$; optimum $\mathrm{pH}$ for growth, 6.8 to 7.0 ; vitamin $\mathrm{B}_{12}$ required as growth factor; $\mathrm{NH}_{4}{ }^{+}$and $\mathrm{NO}_{3}{ }^{-}$used as nitrogen sources; $\mathrm{N}_{2}$ not used as a nitrogen source; negative for denitrification; catalase positive; weakly oxidase positive; urease negative; no hydrolysis of gelatin, casein, starch, agar, or esculin; no indole reaction; methyl red and Voges-Proskauer tests negative; weak $\mathrm{H}_{2} \mathrm{~S}$ production from thiosulfate or L-cysteine; litmus milk negative; no acid or gas produced from $\mathrm{N}$-acetyl-glucosamine, adonitol, amygdalin, amylose, D-(-)arabinose, L-(+)-arabinose, dextrin, dulcitol, erythritol, D- (-)-fructose, galactose, D-(+)-glucose, glycerol, glycogen, $m$-inositol, inulin, lactose, maltose, mannitol, $\mathrm{D}-(+)-$ melezitose, D-(+)-melibiose, methyl-D-glucopyranoside, methyl-D-mannopyranoside, methyl-D-xylopyranoside, D(+)-raffinose, rhamnose, ribose, saccharose, salicin, sorbitol, starch, D- $(-)$-trehalose, D-(+)-xylose, or L- $(-)$-xylose.

The susceptibilities of the 22 strains to 17 different antibiotics are given in Table 2.

Utilization of carbon sources. The different strains were isolated in mineral salts media containing either chloridazon, antipyrin, or pyramidon as the sole carbon source (Table 1). All 22 strains do not utilize all three substrates; the differences are summarized in Table 3. Chloridazon and antipyrin are well utilized by most strains; pyramidon is utilized by only 7 of the 22 isolates. When pyramidon is added to media containing antipyrin or chloridazon, an inhibitory effect is observed.

A number of aromatic or heterocyclic compounds that are structurally related to chloridazon or antipyrin were tested as possible carbon sources. Some of these compounds and the results of growth tests with them are shown in Fig. 4. Most chloridazon analogs with altered heterocyclic moieties were good growth substrates; however, substitution at the aromatic nucleus made the compound inaccessible for the bacteria (o-, $m-, p$-methylchloridazon, $o$-nitrochloridazon).

If the pyridazinone molecule bears two chlorine substituents without an amino group, it is no longer a growth substrate for chloridazon-degrading bacteria, and when added to chloridazon-containing media, this compound acts as a growth inhibitor. Only poor growth was observed with compounds structurally related to antipyrin, like isopropylphenazon, amino-antipyrin, and $N$-phenylpyrrolidinon.

Of the aniline derivatives tested, $N$-methylacetanilide and $N$-methylformanilide were poor growth substrates, and acetanilide, $N$-dimethylaniline, $N$-methylaniline, and aniline were not utilized. In addition, the following aromatic com- 

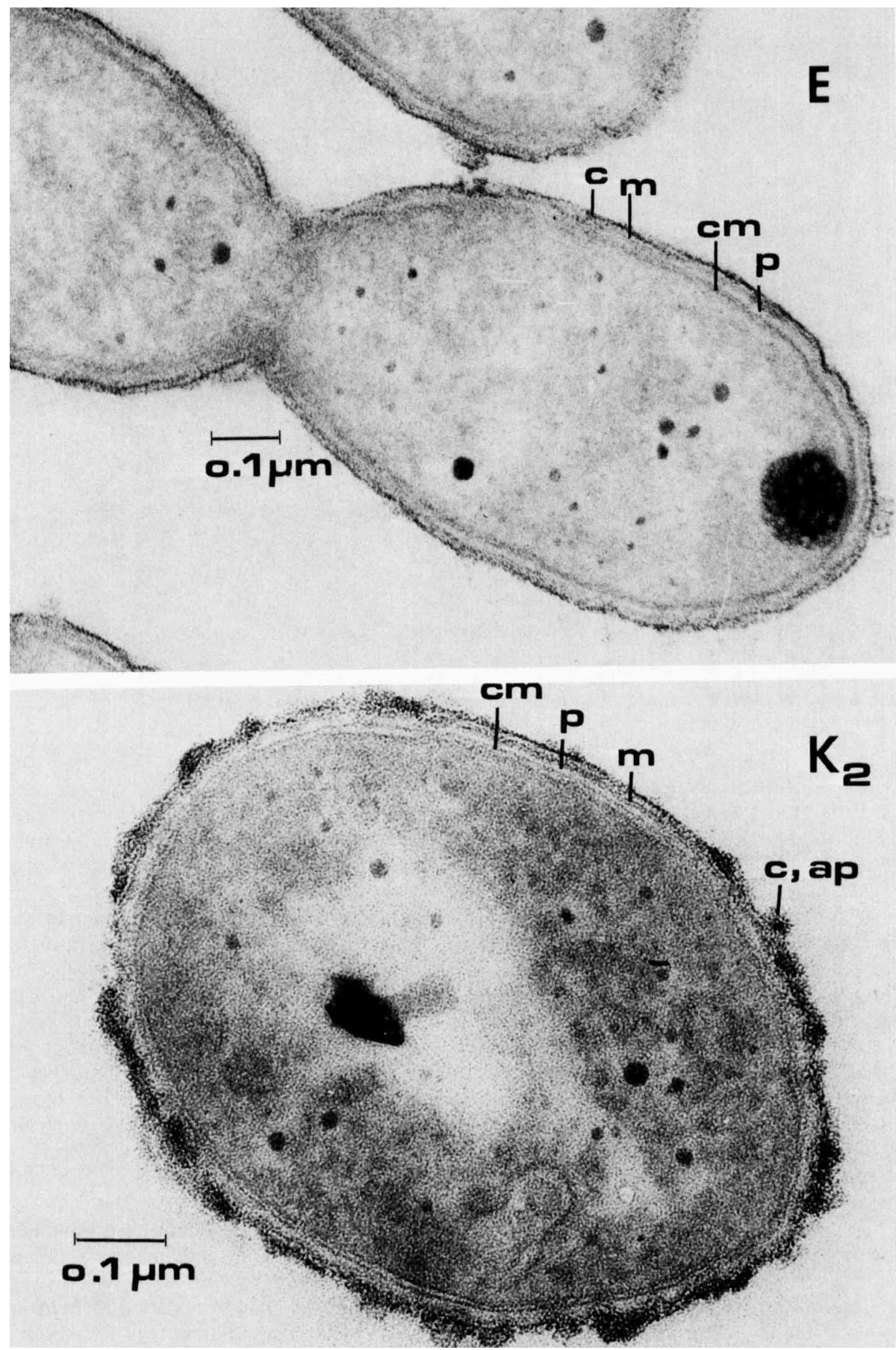

FIG. 3. Ultrathin sections of ruthenium red-treated cells of Phenylobacterium immobile strains $\mathrm{E}^{\mathrm{T}}$ and $\mathrm{K}_{2}$. $\mathrm{cm}$, Cytoplasmic membrane; p, periplasm; m, outer membrane; c, capsule (not stained); c,ap, capsule consisting of acid polysaccharides (stained with ruthenium red).

pounds which usually are degraded by various species of bacteria were not utilized by the chloridazon-degrading bacteria: benzene, toluene, biphenyl, phenol, catechol, resorcinol, pyrogallol, benzoic acid, benzaldehyde, salicylic acid, benzoic acid amide, 2-aminobenzoic acid, 2-,3- and 4-hydroxybenzoic acids, and 2,4-, 2,5-, and 3,5-dihydroxybenzoic acids.

Strain $\mathrm{N}$ was the only strain which grew on L-phenylalanine with a normal lag phase of 1 day. All other strains had lag phases of at least 2 to 3 weeks. The long lag phases occurred only when the strains were transferred from chloridazon or antipyrin to L-phenylalanine for the first time; after additional transfers the organisms grew immediately. Several aromatic compounds that are structurally related to L-phenylalanine, like phenylpropionate, phenylpyruvate, and phenylactate, are also good growth substrates (42). Less effective are phenylacetate, phenylbutyrate, cinnamate, and mandelate, and no growth was observed with L-phenylserine.

The chloridazon-degrading bacteria can use relatively few simple carbon compounds as sole sources of carbon and 
TABLE 2. Susceptibility to antibiotics

\begin{tabular}{|c|c|c|c|c|}
\hline Antibiotic & $\begin{array}{l}\text { Concn } \\
\text { per } \\
\text { disk }\end{array}$ & $\begin{array}{c}\text { No. of } \\
\text { resistant } \\
\text { strains }\end{array}$ & $\begin{array}{l}\text { No. of } \\
\text { susceptible } \\
\text { strains }\end{array}$ & $\begin{array}{c}\text { Avg diam of } \\
\text { inhibition } \\
\text { zone }(\mathrm{mm})\end{array}$ \\
\hline Ampicillin & $10 \mu \mathrm{g}$ & & 22 & 25 \\
\hline Bacitracin & $10 \mu \mathrm{g}$ & & 22 & 41 \\
\hline Cephaloridine & $5 \mu \mathrm{g}$ & 22 & & \\
\hline Chloramphenicol & $10 \mu \mathrm{g}$ & & 22 & 30 \\
\hline Cloxacillin & $5 \mu \mathrm{g}$ & 22 & & \\
\hline Colistin sulfate & $10 \mu \mathrm{g}$ & 16 & 6 & 10 \\
\hline Erythromycin & $10 \mu \mathrm{g}$ & 22 & & \\
\hline Fusidic acid & $10 \mu \mathrm{g}$ & 22 & & \\
\hline Kanamycin & $5 \mu \mathrm{g}$ & & 22 & 21 \\
\hline Lincomycin & $2 \mu \mathrm{g}$ & 22 & & \\
\hline Methicillin & $10 \mu \mathrm{g}$ & 22 & & \\
\hline Neomycin & $10 \mu \mathrm{g}$ & & 22 & 16 \\
\hline Novobiocin & $5 \mu \mathrm{g}$ & 7 & 15 & \\
\hline Penicillin G & $10 U$ & 4 & 18 & 28 \\
\hline Streptomycin & $10 \mu \mathrm{g}$ & & 22 & 16 \\
\hline Tetracycline & $10 \mu \mathrm{g}$ & & 22 & 50 \\
\hline Sulfafurazole & $100 \mu \mathrm{g}$ & 22 & & \\
\hline
\end{tabular}

energy. Growth which was much poorer than growth on chloridazon or L-phenylalanine was observed on L-glutamate, pyruvate, fumarate, succinate, and malate (Table 4). No growth occurred on fructose, galactose, mannose, ribose, xylose, arabinose, saccharose, lactose, maltose, trehalose, inositol, mannitol, erythritol, glycerol, methanol, ethanol, ethanolamine, gelatin, Tween 80 , formiate, acetaldehyde, acetate, propionate, $\beta$-hydroxybutyrate, lactate, oxalate, malonate, tartrate, citrate, adipate, glycolate, and all amino acids except L-phenylalanine and L-glutamate. A mixture of carbon compounds yielded better growth than single carbon compounds (for example, a combination of L-glutamate plus pyruvate), but growth was still considerably less than growth with chloridazon (Table 4). When added to L-glutamate, glucose also showed growth stimulation.

Vitamin $B_{12}$, which in the first studies $(15,18)$ was found to be a growth factor for chloridazon-degrading bacteria, was routinely added to the mineral salts media at a concen-

TABLE 3. Xenobiotic growth substrates utilized by the strains of Phenylobacterium immobile

\begin{tabular}{|c|c|c|c|}
\hline \multirow{2}{*}{ Strain } & \multicolumn{3}{|c|}{ Growth with: } \\
\hline & Chloridazon & Antipyrin & Pyramidon \\
\hline$A_{6}$ & + & + & - \\
\hline$A_{11}$ & - & + & + \\
\hline $\mathrm{A}_{12}$ & + & + & - \\
\hline$A_{13}$ & - & + & - \\
\hline $\mathrm{A}_{14}$ & - & + & - \\
\hline $\mathrm{C}_{2}$ & + & + & + \\
\hline $\mathrm{E}^{\mathrm{T}}$ & + & + & - \\
\hline $\mathrm{J}_{1}$ & + & + & - \\
\hline $\mathrm{J}_{2}$ & + & + & + \\
\hline $\mathrm{K}_{2}$ & + & + & - \\
\hline $\mathrm{K}_{3}$ & + & + & - \\
\hline $\mathrm{K}_{5}$ & + & + & - \\
\hline L & + & + & + \\
\hline $\mathbf{M}_{11}$ & - & + & + \\
\hline $\mathrm{M}_{13}$ & - & + & + \\
\hline $\mathbf{M}_{15}$ & - & + & + \\
\hline $\mathbf{N}$ & + & - & - \\
\hline $\mathbf{R}$ & + & + & - \\
\hline $\mathrm{Z}_{5}$ & + & + & - \\
\hline $\mathrm{Z}_{6}$ & + & + & - \\
\hline $\mathrm{Z}_{7}$ & + & + & - \\
\hline $\mathrm{Z}_{8}$ & + & + & - \\
\hline
\end{tabular}

tration of $30 \mu \mathrm{g} /$ liter. For Pseudomonas diminuta and Pseudomonas vesicularis strains a mixture containing pantothenate $(400 \mu \mathrm{g} /$ liter $)$, biotin $(400 \mu \mathrm{g} /$ liter $)$, vitamin $\mathrm{B}_{12}(400$ $\mu \mathrm{g} /$ liter $)$, and cystine $(50 \mathrm{mg} /$ liter) was necessary for growth (2). The addition of this mixture, however, did not stimulate growth of the chloridazon-degrading bacteria.

Complex media in concentrations which are usual for routine cultivation (10 to $20 \mathrm{~g}$ of peptone, or meat extract plus yeast extract per liter) did not support growth of the chloridazon-degrading bacteria. These bacteria were found to be osmotically sensitive, as demonstrated by $\mathrm{NaCl}$ addition to the chloridazon-mineral salts medium. Considerable growth inhibition was observed at an $\mathrm{NaCl}$ concentration of 5 to $7 \mathrm{~g} /$ liter, and total inhibition was observed at an $\mathrm{NaCl}$ concentration of $10 \mathrm{~g} /$ liter. The chloridazon-degrading bacteria did grow, on complex media supplemented with 0.5 to $2 \mathrm{~g}$ of peptone plus yeast extract per liter, although growth was considerably slower than growth on chloridazon. Growth was observed but was very poor in medium D containing 6.5 $\mathrm{g}$ of yeast extract plus peptone per liter and $2.5 \mathrm{~g}$ of $\mathrm{NaCl}$ per liter.

Degradation of chloridazon. The pathway for the degradation of chloridazon was elucidated by metabolic and enzymatic studies (Fig. 5). In the first step $\mathrm{O}_{2}$ is incorporated into the benzene nucleus in the 2,3 position by the action of a dioxygenase (37). The resulting cis-dihydro-dihydroxy derivative is oxidized by a dehydrogenase, yielding a catechol derivative (14). By the action of a meta-cleaving enzyme (34) a yellow compound is formed, which is cleaved by an amidase to form the heterocyclic moiety of chloridazon and 2-hydroxymuconate (35). 2-Hydroxymuconate is further degraded via 2-oxo-4-hydroxyvalerate (5), yielding pyruvate and acetaldehyde, two compounds of intermediary metabolism, which are potential sources of carbon and energy for the bacterial cells.

The pathway for the degradation of antipyrin (38) and pyramidon (4) closely resembles the pathway summarized above, and in the pathway for the degradation of L-phenylalanine (7) and cinnamate (40) the first steps are the same as those for chloridazon degradation.

$\mathbf{G}+\mathbf{C}$ content. Determinations of DNA $\mathrm{G}+\mathrm{C}$ molar ratios for the different strains yielded values between 65 and 66.5 mol\%. For strain $\mathrm{C}_{2}$ a slightly higher $\mathrm{G}+\mathrm{C}$ ratio, $68.5 \mathrm{~mol} \%$, was found. If the $\mathrm{G}+\mathrm{C}$ determination was run with a mixture of DNAs from strain $C_{2}$ and strain $E^{\mathrm{T}}$, a distinct shoulder was obtained in the ultraviolet scan.

DNA hybridization. Radioactive DNA from chloridazondegrading bacterial strain $\mathrm{R}$ was bound to filters containing homologous unlabeled DNA. The effects of excessive amounts of DNAs isolated from different organisms on the binding of radioactive DNA were tested. Chloridazon-degrading bacterial strains $\mathrm{E}^{\mathrm{T}}, \mathrm{J}_{2}, \mathrm{~L}, \mathrm{~N}$, and $\mathrm{R}$ gave $100 \%$ competition with strain R. No competition was found with DNAs from Agrobacterium tumefaciens, Bacillus subtilis, Escherichia coli, Pseudomonas fuorescens, and calf thymus.

Plasmids. Dye-buoyant density equilibrium centrifugation demonstrated that all strains of chloridazon-degrading bacteria harbor plasmid DNA (23). Agarose gel electrophoresis revealed the presence of at least two different plasmids in all strains, except strain $C_{2}$, which contained only one large plasmid (170 megadaltons) (33). Several strains possessed three, four, or even six plasmids. Regarding plasmid size, considerable variation within the different plasmids of one strain and among the different strains was observed; molecular weights between $8 \times 10^{6}$ and $300 \times 10^{6}$ were found. 
TABLE 4. Doubling times and cell yields in the stationary growth phase of the type strain of Phenylobacterium immobile in minimal medium $\mathrm{B}$ containing different carbon sources

\begin{tabular}{llcc}
\hline \multicolumn{1}{c}{ Growth substrate } & $\begin{array}{c}\text { Concn } \\
(\mathrm{g} / \text { liter })\end{array}$ & $\begin{array}{c}\text { Doubling time } \\
(\mathrm{h})\end{array}$ & $\begin{array}{c}\text { Cell yield } \\
\left(\mathrm{cells} / \mathrm{mi} \times 10^{8}\right)\end{array}$ \\
\hline Chloridazon & 0.4 & 7.5 & 3.2 \\
Antipyrin & 0.4 & 7 & 3.8 \\
Antipyrin & 1.0 & 7.5 & 9.5 \\
Antipyrin & 4.0 & 13 & 13.0 \\
L-Phenylalanine & 1.0 & 8.5 & 12.5 \\
Phenylpropionate & 0.4 & 12 & 4.4 \\
L-Glutamate & 1.0 & 32 & 5.6 \\
Pyruvate & 1.0 & 44 & 5.0 \\
Succinate & 1.0 & 75 & 2.4 \\
L-Glutamate + pyruvate & $1.0($ each) & 20 & 9.4 \\
Yeast extract + peptone & $1.0($ each) & 29 & 6.0 \\
\hline
\end{tabular}

Partial sequence analysis of 16S rRNA. The 16S rRNA from chloridazon-degrading bacterial strain $\mathrm{E}^{\mathrm{T}}$ was isolated and digested with ribonuclease $T_{1}$. The $5^{\prime}$ ends of the oligonucleotides were labeled in vitro with $\left[{ }^{32} \mathrm{P}\right] \mathrm{ATP}$ and phosphatasefree T4 polynucleotide kinase. Fingerprinting and sequence analysis of the labeled oligonucleotides of hexamer size and larger yielded an oligonucleotide catalog (31). This catalog was compared with the oligonucleotide catalogs of more than 400 microorganisms which were analyzed previously by this method. $\mathrm{S}_{\mathrm{AB}}$ values were calculated from a comparison of the catalogs. On the basis of these results, the chloridazondegrading organism is not closely related to any bacterium investigated so far with this method. The highest $S_{A B}$ values (0.51), indicating only a remote relationship, were found with Pseudomonas diminuta and Rhizobium leguminosarum.

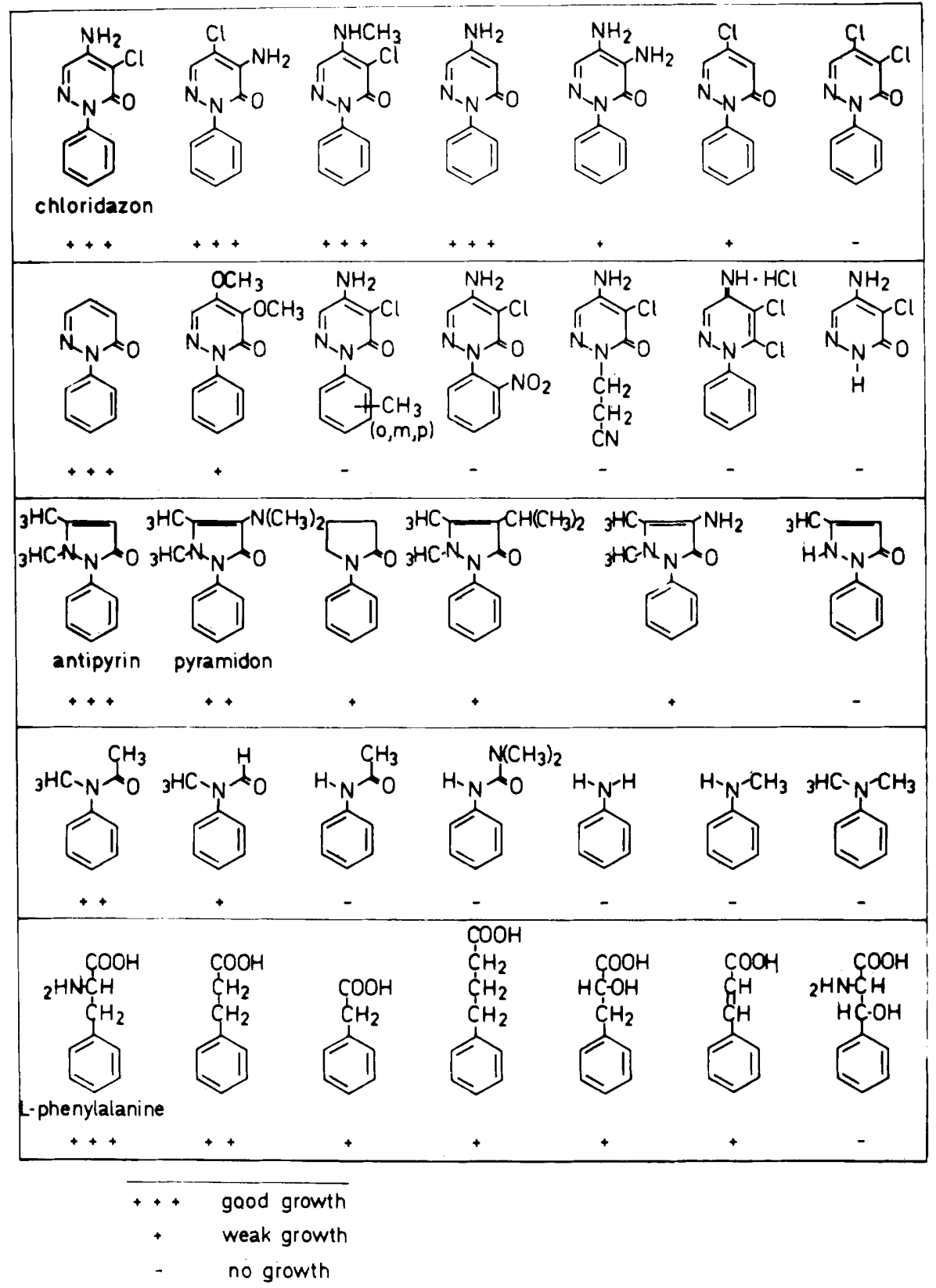

FIG. 4. Compounds that are structurally related to chloridazon and their utilization as sole sources of carbon and energy. 


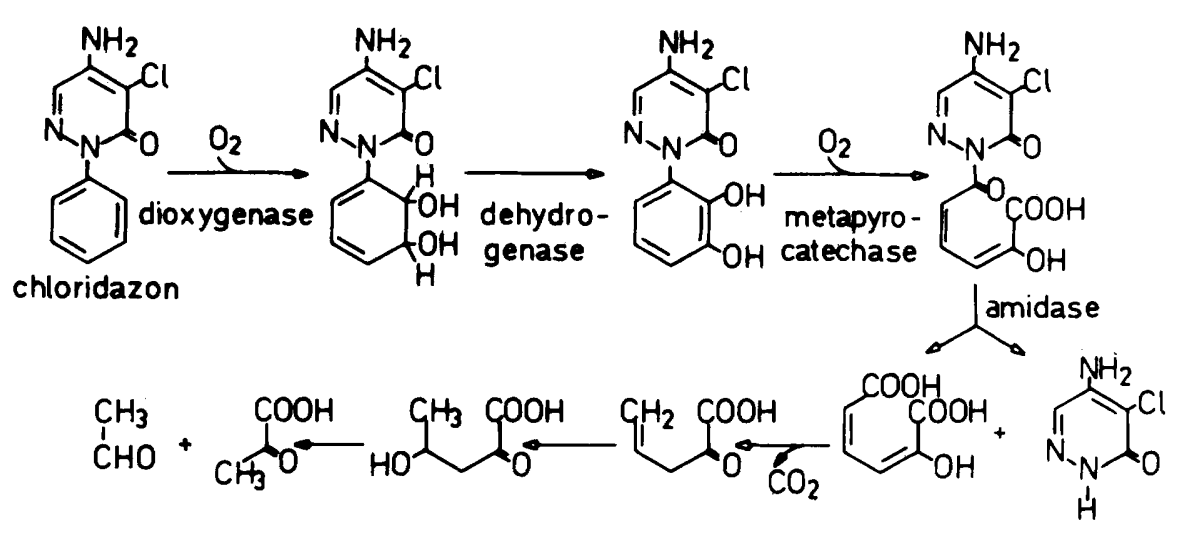

FIG. 5. Pathway for degradation of chloridazon.

Lipopolysaccharide. The lipopolysaccharide of strain $\mathrm{E}^{\mathrm{T}}$ was obtained by two-stage extraction with phenol-ethylenediaminetetraacetate, and its composition was analyzed by a combination of chemical procedures, gas chromatography, mass spectrometry, paper electrophoresis, and enzymatic tests (43). The carbohydrate moiety was found to consist of heptose, 3-deoxyoctulosonic acid, and D-glucose in a molar ratio of 1:2:2.3. Lipid $A$ is composed of 1 mol of 2,3-diamino2,3-dideoxy-D-glucose and $2 \mathrm{~mol}$ of amide-bound and 2.6 mol of ester-bound fatty acids per mol. The amide-bound fatty acids were identified as 3-hydroxydodecanoic acid and 3-hydroxyhexadecanoic acid. $R$-(-)-3-hydroxydodec-5-cisenoic acid and dodecanoic acid were found to be ester linked. Dodecanoic acid was demonstrated to be linked additionally with the hydroxy groups of the amide-bound fatty acids.

Murein analysis. The composition of the murein from strain $\mathrm{E}^{\mathrm{T}}$, which was obtained by differential centrifugation of cell envelopes and treatment with sodium dodecyl sulfate, is shown in Table 5. The contents of glutamic acid and

TABLE 5. Composition of the murein from the type strain of Phenylobacterium immobile

\begin{tabular}{l|c|c|c|c}
\hline & \multicolumn{3}{|c|}{ Phenylobacterium immobile } & \\
\cline { 2 - 4 } Constituent & $\begin{array}{c}\text { Murein after } \\
\text { differential } \\
\text { centrifugation } \\
\text { and sodium } \\
\text { dodecyl } \\
\text { sulfate } \\
\text { treatment }\end{array}$ & $\begin{array}{c}\text { Murein after } \\
\text { differential } \\
\text { centrifugation, } \\
\text { sodium } \\
\text { dodecyl } \\
\text { sulfate } \\
\text { treatment, and } \\
\text { pronase } \\
\text { digestion }\end{array}$ & $\begin{array}{c}\text { Muropeptides } \\
\text { from lysozyme- } \\
\text { treated murein } \\
\text { after gel } \\
\text { chromatography }\end{array}$ & $\begin{array}{c}\text { E. coli } \\
\text { murein }\end{array}$ \\
\hline Muramic acid & 1.16 & 0.82 & 1.02 & 0.85 \\
Glutamic acid & 3.79 & 2.49 & 1.03 & 1.10 \\
Alanine & 2.49 & 1.78 & 1.80 & 1.77 \\
Diaminopimelic & 1.0 & 1.0 & 1.0 & 1.0 \\
$\begin{array}{l}\text { acid } \\
\text { Glucosamine }\end{array}$ & 1.06 & 0.97 & 0.98 & 1.0 \\
Aspartic acid & 0.15 & 0.02 & & \\
Threonine & 0.14 & 0.01 & & \\
Serine & 0.11 & 0.04 & & \\
Glycine & 0.32 & 0.10 & & \\
Leucine & 0.08 & 0.07 & \\
\hline
\end{tabular}

a The values are related to the concentration of diaminopimelic acid. Other amino acids in acid protein hydrolysates not listed had values of less than 0.05 . alanine were higher than expected for the murein of a gram-negative bacterium. A lipoprotein attached to the murein as described for $E$. coli was not present in the chloridazon-degrading organism. The murein was further purified by pronase digestion, and the values for amino acids, which were assumed not to be constituents of the murein, dropped considerably. The value for glutamic acid, however, was still too high for a normal murein of a gram-negative bacterium. A comparison of the lysozyme degradation products with those of $E$. coli by thin-layer chromatography revealed that the main component from the chloridazon-degrading bacterium was identical to the $\mathrm{C}_{6}$ muropeptide (Glc NAc-Mur NAc-Ala-Glu-A $A_{2}$ pm-Ala) of $E$. coli. The amino acid composition of the muropeptides isolated after Sephadex G-25 chromatography of lysozymetreated murein was also almost identical to that of $E$. coli (Table 5). The high glutamic acid content have been due to an impurity, probábly polyglutamic acid.

Serology. By injecting Formalin-treated bacteria intravenously into rabbits, antisera against chloridazon-degrading bacterial strains $\mathrm{E}^{\mathrm{T}}, \mathrm{K}_{2}, \mathrm{M}_{11}$, and $\mathrm{N}$ were prepared. Agglutination tests and immunofluorescence tests revealed the serological uniformity of the 22 chloridazon-degrading strains (25). On the basis of differences in agglutination reactions, antibody titers, and immunofluorescence data, the bacterial strains were classified into five serological subgroups. No serological relationship was found between chloridazon-degrading bacteria and 40 representative gram-negative bacteria, including Acetobacter aceti, Achromobacter parvulus, Acinetobacter calcoaceticus, Agrobacterium tumefaciens, Alcaligenes faecalis, Azospirillum brasiliense, Caulobacter sp., E. coli, Flavobacterium sp., Paracoccus dentirificans, Pseudomonas acidovorans, Pseudomonas aeruginosa, $P$ seudomonas diminuta, Pseudomonas fluorescens, Pseudomonas lemoignei, Pseudomonas putida, Pseudomonas sp., Pseudomonas stutzeri, Pseudomonas testosteroni, Rhizobium sp., Rhodomicrobium vannielii, Rhodopseudomonas capsulata, and Salmonella typhimurium. A slight but significant immunofluorescence reaction was observed when antisera against chloridazon-degrading bacteria were allowed to react with Pseudomonas vesicularis, Gluconobacter oxydans, and Aquaspirillum itersonii (Dorfer et al., unpublished data).

Enzymatic investigations. (i) Citric acid cycle. The presence and some properties of the enzymes that catalyze citric acid cycle reactions and anaplerotic sequences were tested in a cell-free extract of strain $\mathrm{E}^{\mathrm{T}}$. This organism was found to possess all of the enzymes of the citric acid cycle and 
enzymatic activities for at least four anaplerotic routes (Table 6).

Several properties of citrate synthase, an enzyme assumed to be of taxonomic significance (44), were studied; by using gel filtration on Sephadex G-200, a molecular weight of 120,000 was found, and the $\mathrm{pH}$ optimum was determined to be 8.0 . The addition of $0.02 \mathrm{M} \mathrm{NaCl}$ and $0.02 \mathrm{M}$ adenosine monophosphate had no influence on the enzyme activity. $\mathrm{KCl}(0.02 \mathrm{M})$ slightly stimulated $(125 \%), \mathrm{NH}_{4} \mathrm{Cl}(0.2 \mathrm{M})$ inhibited $(48 \%)$, and $\mathrm{MgCl}_{2}(0.2 \mathrm{M})$ and $\mathrm{CaCl}_{2}(0.2 \mathrm{M})$ completely inhibited the enzyme reaction. Adenosine triphosphate $(0.01 \mathrm{M})$ caused $30 \%$ inhibition, and 2-ketoglutarate $(0.01 \mathrm{M})$ and $\mathrm{NADH}(0.25 \mathrm{mM})$ resulted in complete inhibition of enzyme activity. The addition of $\mathrm{KCl}$ did not influence 2-ketoglutarate inhibition, and the addition of adenosine monophosphate to $\mathrm{NADH}$ had no influence on the inhibitory effect of NADH.

(ii) Rhodanese. Rhodanese has been demonstrated in various organisms and has been discussed as a tool which has potential taxonomic significance (41).

Rhodanese activity has been found in all strains of the chloridazon-degrading bacteria, and the specific activities, the $\mathrm{pH}$ optima, and molecular weights of the enzymes have been determined (26). The enzymes had a pH optimum of 11 ; molecular weights between 14,000 and 16,000 were found. Specific activities ranged between 0.16 and $1.9 \mathrm{mU} / \mathrm{mg}$.

(iii) Arogenate dehydrogenase. The existence of one or two pathways (namely, the 4-hydroxy-phenylpyruvate or arogenate pathway or both) for tyrosine biosynthesis and the properties of the enzymes which catalyze these routes have been used for comparative taxonomic studies (29).

Chloridazon-degrading bacterial strain $\mathrm{E}^{\mathrm{T}}$ was found to synthesize tyrosine via arogenate exclusively (22). Arogenate dehydrogenase utilized either oxidized nicotinamide adenine dinucleotide or oxidized nicotinamide adenine dinucleotide phosphate as a hydrogen acceptor. This enzyme did not show significant regulation by repression and induction. The activity of the enzyme was not influenced by L-tyrosine or L-phenylalanine.

(iv) meta-Cleaving enzymes. Chloridazoncatechol, an intermediate in chloridazon degradation, is cleaved in meta-proximal position by a chloridazoncatechol dioxygenase. The properties of this enzyme were investigated in 12 strains of chloridazon-degrading bacteria (strains $A_{11}, A_{13}, A_{14}, E^{T}, J_{1}$,

TABLE 6. Citric acid cycle enzymes and enzymes catalyzing anaplerotic routes in the type strain of Phenylobacterium immobile

\begin{tabular}{|c|c|}
\hline Enzyme & Sp act (U/mg) \\
\hline \multicolumn{2}{|l|}{ Citric acid cycle: } \\
\hline Aconitase... & 47 \\
\hline Isocitrate dehydrogenase & 2 \\
\hline 2-Ketoglutarate dehydrogenase. . & 0.002 \\
\hline Succinyl-coenzyme A synthase. . & 0.0005 \\
\hline Succinate dehydrogenase . . & 1 \\
\hline Fumarase...$\ldots \ldots \ldots$ & 0.1 \\
\hline Malate dehydrogenase. & 10 \\
\hline Citrate synthase ..... & 0.06 \\
\hline \multicolumn{2}{|l|}{ Anaplerotic sequences } \\
\hline Isocitrate lyase (glyoxylate cycle) & 0.0002 \\
\hline Malate synthase (glyoxylate cycle) & 0.0002 \\
\hline Phosphoenolpyruvate carboxylase. & 0.003 \\
\hline Pyruvate carboxylase $\ldots \ldots \ldots \ldots$ & 0.0007 \\
\hline Malic enzyme...$\ldots \ldots$ & 0.0005 \\
\hline
\end{tabular}

$\mathrm{J}_{2}, \mathrm{~K}_{2}, \mathrm{~L}, \mathrm{M}_{11}, \mathrm{M}_{13}, \mathrm{M}_{15}$, and $\mathrm{N}$ ) and compared with the properties of meta-cleaving enzymes from seven other bacteria (39). These bacteria belonged to various Pseudomonas, Acinetobacter, and Nocardia species, and were isolated with aromatic compounds such as toluene, benzoate, 4-chlorobenzoate, 3-phenylpropionate, and papaverine. Doublediffusion experiments with antibodies prepared against chloridazoncatechol dioxygenase from strain $\mathrm{E}^{\mathrm{T}}$ and the kinetic behavior of the meta-cleaving enzymes (substrate specificity and requirement for $\mathrm{Fe}^{2+}$ ions for activity) revealed the uniformity of the chloridazon catechol dioxygenases, which seem to form a distinct group among the nonheme iron-containing dioxygenases.

Toxicity of chloridazon-degrading bacteria. Cells of strains $\mathrm{E}^{\mathrm{T}}$ and $\mathrm{N}$ were orally administered to rats for 7 days. No adverse reactions were observed (21). Exposure by air in inhalation experiments did not lead to specific pulmonary changes. Intracutaneous injection of cells did not lead to adverse skin reactions, and intraperitoneal injections of cells did not kill the rats, although bacteria entered the blood. Intravenous injections of living and Formalin-killed bacteria into rabbits during immunization procedures did not lead to toxic effects.

\section{DISCUSSION}

Homogeneity of the strains. Morphological, physiological, biochemical, and nutritional studies, serological and enzymological data, and the results of DNA $\mathrm{G}+\mathrm{C}$ determinations and DNA hybridizations have demonstrated the high degree of similarity among the 22 isolates of chloridazon-degrading bacteria. It seems reasonable to group these strains together in a single species. On the other hand, minor but significant differences exist in serological and enzyme properties, in plasmid pattern, and in the utilization of the xenobiotic compounds chloridazon, antipyrin, and pyramidon; this allows us to propose a subgroup classification of the isolates $(25,39)$.

Failure to identify chloridazon-degrading bacteria. All attempts to identify the chloridazon-degrading bacteria on the basis of routine characters led to unsatisfactory results. The high nutritional specialization of these bacteria, which grow optimally on man-made compounds and utilize poorly only a few normal carbon sources, and the fact that nearly all biochemical tests give negative results are their most distinguishing features. Considering the 19 parts of Bergey's Manual of Determinative Bacteriology, 8th ed. (6), part 7 (gram-negative aerobic rods and cocci) and part 10 (gramnegative cocci and coccobacilli) seem to be most appropriate. Part 10 includes the genus Acinetobacter, which in the first attempt to identify the chloridazon-degrading bacteria was taken into consideration. This genus must be excluded, since the $\mathrm{G}+\mathrm{C}$ values of the herbicide-degrading organism is not in accordance with Acinetobacter values. More morphological, physiological, biochemical, and nutritional features are shared with the genus Pseudomonas. The general morphological characteristics of Pseudomonas, however, exclude nonmotile organisms. All other genera of part 7 and part 10 show fewer similarities with the organisms of this study.

The view that chloridazon-degrading bacteria are not related to Acinetobacter or Pseudomonas or to numerous other species which were studied for comparison is supported by serological and enzymological investigations. Thus, the results of studies on the molecular and kinetic properties of rhodanese (26), the biosynthetic route for tyrosine synthesis (22), and the substrate specificity, kinet- 
ics, and immunology of meta-cleaving enzymes (39) demonstrated that the chloridazon-degrading bacteria have enzyme properties which are clearly different from those of Pseudomonas and Acinetobacter.

The regulatory properties of the citrate synthase from strain $E^{T}$ are similar to those of the enzymes from facultatively anaerobic gram-negative bacteria, like members of the Enterobacteriaceae. The low molecular weight $(120,000)$ of the citrate synthase and the fact that it was impossible to abolish 2-ketoglutarate inhibition by adding $\mathrm{KCl}$ and $\mathrm{NADH}$ inhibition by adding adenosine monophosphate are different than the properties described for members of the Enterobacteriaceae, thus indicating the exceptional properties of the citrate synthase from the herbicide-degrading organism (44).

Phylogenetic position of the chloridazon-degrading bacteria. Serological investigations on the chloridazon-degrading bacteria also demonstrated that these organisms are not closely related to a variety of gram-negative bacteria (25). Only slight immunological relatedness to Pseudomonas vesicularis, Gluconobacter suboxydans, and Aquaspirillum itersonii was detected (Dorfer et al., unpublished data).

A partial sequence analysis of $16 \mathrm{~S}$ rRNA, which is a powerful method for the elucidation of even remote relationships among microorganisms, also revealed the isolated position of the chloridazon-degrading bacteria (31). The highest $\mathrm{S}_{\mathrm{AB}}$ values $(0.51)$ were found with Pseudomonas diminuta and Rhizobium leguminosarum. $\mathrm{S}_{\mathrm{AB}}$ values of this magnitude indicate a rather remote relationship, which would not be detectable by DNA-DNA hybridization. A comparison of $16 \mathrm{~S}$ rRNA nucleotide catalogs showed that the chloridazon-degrading bacteria are members of group I of the purple nonsulfur bacteria (19). $\mathrm{S}_{\mathrm{AB}}$ values ranging from 0.46 to 0.49 were detected with Rhodopseudomonas viridis, Rhodopseudomonas capsulata, Rhodopseudomonas sphaeroides, Rhodomicrobium vannielii, and Aquaspirillum itersonii. With representatives of the other major groups of gram-negative bacteria, including Acinetobacter calcoaceticus and the two main phylogenetically defined clusters of the genus Pseudomonas, $\mathrm{S}_{\mathrm{AB}}$ values between 0.23 and 0.32 were found, indicating a wide phylogenetic distance.

The relationship of the chloridazon-degrading bacteria to members of the subgroup Ib of the purple nonsulfur bacteria is supported by the lipopolysaccharide composition of this organism (43). Members of this group contain 2,3-diamino2,3-dideoxy-D-glucose, as demonstrated in Rhodopseudomonas viridis and Rhodopseudomonas palustris (36), Rhodopseudomonas sulfoviridis (1), Pseudomonas diminuta (45), and Nitrobacter species (32).

Most of the remote relatives of the chloridazon-degrading bacteria exhibit features which clearly distinguish them from the organisms described in this paper. The rhizobia are described as motile, and they utilize a great variety of carbon sources and have the capacity to nodulate leguminous hosts. Also, the members of the genera Rhodopseudomonas and Rhodomicrobium, with their photosynthetic capacity, and Aquaspirillum, with its unique morphology, are phenotypically quite different from the chloridazon-degrading bacteria. Pseudomonas diminuta was originally defined by its unusual flagellar structure. This organism is monotrichous, and the flagellum is very small and tightly coiled (27). Investigations of Pseudomonas diminuta and Pseudomonas vesicularis strains showed that these organisms utilize a quite limited range of carbon sources and require pantothenate, biotin, and cyanocobalamin as growth factors (2). The nutritional spectrum, the requirement of growth factors, and the DNA G+C values of 66.3 to $67.3 \mathrm{~mol} \%$ for Pseudomonas diminuta and $65.8 \mathrm{~mol} \%$ for Pseudomonas vesicularis are similar to the properties of chloridazon-degrading bacteria. Therefore, the ability of Pseudomonas diminuta and Pseudomonas vesicularis to utilize chloridazon or antipyrin was tested. The result was negative, and also negative was an experiment to stimulate growth of chloridazon-degrading bacteria by adding the Pseudomonas diminuta growth factors. Interestingly, with Pseudomonas vesicularis but not with Pseudomonas diminuta a weak immunofluorescence reaction with antisera against the chloridazon-degrading bacteria was found (Dorfer et al., unpublished data). Based on the DNA-rRNA hybridization experiments of De Vos and De Ley (12) and a 16S rRNA analysis (C. R. Woese et al., manuscript in preparation), Pseudomonas diminuta and Pseudomonas vesicularis are misnamed species and not members of the genus Pseudomonas. As nonmotile Pseudomonas-like organisms, the chloridazon-degrading bacteria show the highest degree of relationship to these misnamed pseudo-pseudomonads, but it is quite clear that they cannot be identified as Pseudomonas vesicularis or Pseudomonas diminuta.

Ecological considerations. The technique for the enrichment of chloridazon-degrading bacteria is based on selective pressure exerted on a microbial population. This technique leads to the isolation of bacteria which are able to utilize synthetic molecules not normally encountered in nature. We suppose that these organisms have sufficient selective advantage only under the conditions of the special isolation process. Obviously, the chemical nature of the selective agent (heterocyclic plus phenyl moiety) is a special challenge for microbial cells, for which other well-described bacterial taxa do not have the right response. This hypothesis is supported by unsuccessful efforts to isolate the same organisms with L-phenylalanine as the selective agent (U. Tittmann and F. Lingens, unpublished data).

Enrichment technique and nutrition characteristics raise the question of which substrates are used by these bacteria in their natural environment. Chloridazon, antipyrin, and pyramidon do not occur in nature; nevertheless, we have shown that these bacteria occur all over the world. Recent experiments with an immunofluorescence membrane filter technique demonstrated that these organisms, or serologically closely related organisms, also occur in soils which have never been treated with the herbicide (Layh and Lingens, unpublished data). This means that these bacteria utilize some other substrate(s) in nature, like L-phenylalanine or structurally related molecules or perhaps mixtures of various organic compounds, like pyruvate, succinate, and L-glutamate, which allow slow growth.

In the last two decades in our laboratory the breakdown of numerous organic molecules, including 4-chlorobenzoate, 4-chlorophenylacetate, $o$-toluidine, $p$-toluidine, biphenyl, carboxanilide fungicides, caffeine, ephedrine, papaverine, L-phenylalanine, and juglone, has been studied. In all cases and in many other examples described in the literature, bacteria with degradative capacity were isolated and could be identified without difficulty. So far, chloridazon seems to be an exception rather than the standard case.

We propose to introduce the chloridazon-degrading bacteria as a new genus with the name Phenylobacterium (Phe.ny.lo.bac' ter.i.um. G. noun phen benzene; L. noun bacterium bacterium; Phenylobacterium benzene bacterium) due to the unique growth characteristics of these bacteria, which predominantly utilize compounds with a phenyl moiety. All of the chloridazon-degrading bacteria 
belong to one species, Phenylobacterium immobile (im.mo' bi.le. L. adj. immobile, nonmotile).

Description of Phenylobacterium immobile gen. nov., sp. nov. Cells are rods, coccal rods, or cocci, 0.7 to 1.0 by 1.0 to $2.0 \mu \mathrm{m}$, and occur singly, in pairs, or in short chains. Some strains tend to clump. In old cultures pleomorphic forms, such as long rods ( 1.0 by 2.0 to $4.0 \mu \mathrm{m}$ ), long chains (10 to 50 $\mu \mathrm{m})$ connected by filaments, and elliptical forms, may occur.

Nonmotile.

Do not produce sheaths or prosthecae.

Resting stages not known.

Capsule stain negative; flexible capsule present.

Not acid fast.

Gram negative.

Growth on agar slow. Colonies small ( 1 to $2 \mathrm{~mm}$ after 2 to 3 weeks), colorless. Colonies may be smooth, convex, moist with shiny surfaces and entire edges, and easily emulsified in saline or rather rough, dry, and not emulsifiable in saline.

In liquid media slight production of greenish yellow nonfluorescent pigment; in L-phenylalanine cultures production of yellowish green fluorescent pigment.

Chemoorganotrophic; metabolism respiratory, never fermentative.

Osmotically sensitive.

Vitamin $B_{12}$ is required as a growth factor.

High nutritional specialization. Good growth on chloridazon, antipyrin, pyramidon, and L-phenylalanine. Slow growth on L-glutamate, pyruvate, fumarate, succinate, and malate and on diluted complex media. Most sugars, alcohols, amino acids, carboxylic acids, and ordinary complex media are not utilized.

Temperature for optimum growth, 28 to $30^{\circ} \mathrm{C}$. No growth at 4 and $37^{\circ} \mathrm{C}$. At $37^{\circ} \mathrm{C}$ cultures die within several days. $\mathrm{pH}$ value for optimum growth, 6.8 to 7.0 .

Isolated from soil after enrichment in mineral media containing chloridazon, antipyrin, or pyramidon.

Do not denitrify; do not produce nitrite from nitrate. $\mathrm{NH}_{4}{ }^{+}$and $\mathrm{NO}_{3}{ }^{-}$are used as sole sources of nitrogen. No growth with $\mathrm{N}_{2}$.

Catalase positive.

Weakly oxidase positive.

Gelatin, casein, starch, and esculin not hydrolyzed.

Urease negative.

Litmus milk negative.

Weak $\mathrm{H}_{2} \mathrm{~S}$ production from thiosulfate or cysteine.

Methyl red and Voges-Proskauer negative.

No indole reaction.

No acid and no gas produced from sugars and alcohols.

All strains susceptible to tetracycline, ampicillin, chloramphenicol, kanamycin, streptomycin, and neomycin. Some of the strains susceptible to penicillin $G$ and novobiocin. All strains resistant to cloxacillin, cephaloridine, erythromycin, fusidic acid, lincomycin, methicillin, and sulfafurazole.

Serological uniformity is shown by members of the genus.

Bacteria are harmless when tested with rats or rabbits.

$\mathrm{G}+\mathrm{C}$ content: 65 to $68.5 \mathrm{~mol} \%$.

Type species: Phenylobacterium immobile sp. nov. The type strain of Phenylobacterium immobile is strain E (DSM 1986).

Description of Phenylobacterium immobile (type strain). Morphology and physiology as for the genus.

Member of group I of purple nonsulfur bacteria, based on $16 \mathrm{~S}$ rRNA sequence analysis.

Contains 2,3-diamino-2,3-dideoxy-D-glucose as a lipopolysaccharide constituent.

Murein composition as for a normal gram-negative bacterium.
All enzymes of citric acid cycle are present.

$\mathrm{G}+\mathrm{C}$ content: $65.5 \mathrm{~mol} \%$.

\section{ACKNOWLEDGMENTS}

This work was supported by the Deutsche Forschungsgemeinschaft and the Fonds der Chemischen Industrie.

We thank E. Beck and G. Schubert, Institut für Zoologie, Hohenheim, Federal Republic of Germany, for electron microscopy and K. Hantke, Institut für Mikrobiologie, Tübingen, Federal Republic of Germany, for the murein analysis. We gratefully acknowledge the expert technical assistance of U. Koch, B. Müller, B. Osswald, and B. Wagner.

\section{LITERATURE CITED}

1. Ahamed, N. M., H. Mayer, H. Biebl, and J. Weckesser. 1982. Lipopolysaccharide with 2,3-diamino-2,3-dideoxyglucose containing lipid A in Rhodopseudomonas sulfoviridis. FEMS Microbiol. Lett. 14:27-30.

2. Ballard, R. W., M. Doudoroff, and R. Y. Stanier. 1968. Taxonomy of the aerobic pseudomonads: Pseudomonas diminuta and $P$. vesiculare. J. Gen. Microbiol. 53:349-361.

3. Blecher, H., R. Blecher, R. Müller, and F. Lingens. 1978. Isolierung und Charakterisierung Antipyrin-abbauender Bakterien. Z. Naturforsch. 33:120-123.

4. Blecher, H., R. Blecher, W. Wegst, J. Eberspächer, and F. Lingens. 1981. Bacterial degradation of aminopyrine. Xenobiotica 11:749-754.

5. Blobel, F., J. Eberspächer, and F. Lingens. 1976. Enzymatische Bildung von 2-Keto-4-hydroxyvaleriansäure mit Hilfe von Pyrazon-abbauenden Bakterien. Z. Naturforsch. Teil C 31:757.

6. Buchanan, R. E., and N. E. Gibbons (ed.). 1974. Bergey's manual of determinative bacteriology, 8th ed. The Williams \& Wilkins Co., Baltimore.

7. Buck, R., J. Eberspächer, and F. Lingens. 1979. Abbau und Biosynthese von L-Phenylalanin in Chloridazon-abbauenden Bakterien. Hoppe Seyler's Z. Physiol. Chem. 360:957-969.

8. Burton, K. 1956. A study of the conditions and mechanism of the diphenylamine reaction for the colorimetric estimation of deoxyribonucleic acid. Biochem. J. 62:315-323.

9. Braun, V., and U. Sieglin. 1970. The covalent murein-lipoprotein structure of the Escherichia coli cell wall. Eur. J. Biochem. 13:336-346.

10. Costerton, J. W., R. T. Irvin, and K. J. Cheng. 1981. The bacterial glycocalyx in nature and disease. Annu. Rev. Microbiol. 35:299-324

11. Denhardt, D. T. 1966. A membrane-filter technique for the detection of complementary DNA. Biochem. Biophys. Res. Commun. 23:641-646.

12. De Vos, P., and J. De Ley. 1983. Intra- and intergeneric simlarities of Pseudomonas and Xanthomonas ribosomal ribonucleic acid cistrons. Int. J. Syst. Bacteriol. 33:487-509.

13. Drescher, N., and S. Otto. 1969. Über den Abbau von 1-Phenyl4-amino-5-chlor-pyridazon-6 (Pyrazon) im Boden. Z. Pfanzenkr. Pflanzenschutz 76:27-33.

14. Eberspächer, J., and F. Lingens. 1978. Reinigung und Eigenschaften von zwei Chloridazondihydrodiol-Dehydrogenasen aus Chloridazon-abbauenden Bakterien. Hoppe Seyler's Z. Physiol. Chem. 359:1323-1334.

15. Engvild, K. C., and H. L. Jensen. 1969. Microbiological decomposition of the herbicide Pyrazon. Soil Biol. Biochem. 1:295-300.

16. Flossdorf, J. 1983. A rapid method for the determination of the base composition of bacterial DNA. J. Microbiol. Methods $1: 305-311$.

17. Frank, R., and C. M. Switzer. 1969. Behaviour of Pyrazon in soil. Weed Sci. 17:323-326.

18. Fröhner, C., O. Oltmanns, and F. Lingens, 1970. Isolierung und Charakterisierung Pyrazon-abbauender Bakterien. Arch. Mikrobiol. 74:82-89.

19. Gibson, J., E. Stackebrandt, L. B. Zablen, R. Gupta, and C. R. Woese. 1979. A phylogenetic analysis of purple photosynthetic bacteria. Curr. Microbiol. 3:59-64.

20. Goebel, W., and H. Schrempf. 1972. Isolation of minicircular deoxyribonucleic acids from wild strains of Escherichia coli and 
their relationship to other plasmids. J. Bacteriol. 111:696-704.

21. Kaiser, A., H.-G. Classen, J. Eberspächer, and F. Lingens. 1981. Acute toxicity testing of some herbicides-, alcaloids-, and antibiotics-metabolizing soil bacteria in the rat. Zentralbl. Bakteriol. Parasitenkd. Infektionskr. Hyg. Abt. 1 Orig. Reihe B 173:173-179.

22. Keller, B., E. Keller, and F. Lingens. 1982. Arogenate (pretyrosine) as an obligatory intermediate of the biosynthesis of L-tyrosine in chloridazon-degrading bacteria. FEMS Microbiol. Lett. 13:121-123.

23. Kreis, M., J. Eberspächer, and F. Lingens. 1981. Detection and characterization of plasmids in chloridazon and antipyrin degrading bacteria. Zentralbl. Bakteriol. Parasitenkd. Infektionskr. Hyg. Abt. 1 Orig. Reihe C 2:45-60.

24. Lautrop, H. 1974. Acinetobacter, p. 436-438. In R. E. Buchanan and N. E. Gibbons (ed.), Bergey's manual of determinative bacteriology. 8th ed. The Williams \& Wilkins Co., Baltimore.

25. Layh, G., R. Böhm, J. Eberspächer, and F. Lingens. 1983. Serological studies on chloridazon-degrading bacteria. Syst. Appl. Microbiol. 4:459-469.

26. Layh, G., J. Eberspächer, and F. Lingens. 1982. Rhodanese in chloridazon-degrading bacteria. FEMS Microbiol. Lett. 15: 23-26.

27. Leifson, E., and R. Hugh. 1954. A new type of polar monotrichous flagellation. J. Gen. Microbiol. 10:68-70.

28. Lingens, F., R. Blecher, H. Blecher, and U. Koch. 1977. Isolierung Chloridazon-abbauender Bakterien aus ostafrikanischen Bodenproben (Kenia). Z. Pflanzenkr. Pflanzenschutz 84: $684-690$.

29. Lingens, F., and E. Keller. 1983. Zur Biosynthese von Phenylalanin und Tyrosin. Arogensäure, ein neues Zwischenprodukt. Naturwissenschaften 70:115-118.

30. Lowenstein, J. (ed.). 1969. Methods in enzymology, vol. 13. Academic Press, Inc., New York.

31. Ludwig, W., J. Eberspächer, F. Lingens, and E. Stackebrandt. 1984. 16S ribosomal RNA studies on the relationship of a chloridazon-degrading gram-negative eubacterium. Syst. Appl. Microbiol. 5:241-246.

32. Mayer, H., E. Bock, and J. Weckesser. 1983 . 2,3-Diamino-2,3dideoxyglucose containing lipid A in the Nitrobacter strain X14. FEMS Microbiol. Lett. 17:93-96.

33. Mötzung, T. 1983. Uber das Vorkommen von Plasmiden in
Chloridazon-abbauenden Bakterien aus australischer Erde. Diplomarbeit, Hohenheim, Federal Republic of Germany.

34. Müller, R., S. Haug, J. Eberspächer, and F. Lingens. 1977. Catechol-2,3-Dioxygenase aus Pyrazon-abbauenden Bakterien. Hoppe Seyler's Z. Physiol. Chem. 358:797-805.

35. Müller, R., and F. Lingens. 1980. Enzymatische Bildung und Isolierung von 2-Hydroxymuconsäure, ein Metabolit im bakteriellen Abbau des Herbizids Chloridazon. Z. Naturforsch. Teil C 35:346-347.

36. Roppel, J., H. Mayer, and J. Weckesser. 1975. Identification of a 2,3-diamino-2,3-dideoxyhexose in the lipid A component of lipopolysaccharides of Rhodopseudomonas viridis and Rhodopseudomonas palustris. Carbohydr. Res. 40:31-40.

37. Sauber, K., C. Fröhner, G. Rosenberg, J. Eberspächer, and F. Lingens. 1977. Purification and properties of pyrazon dioxygenase from pyrazon-degrading bacteria. Eur. J. Biochem. 74:89-97.

38. Sauber, K., R. Müller, E. Keller, J. Eberspächer, and F. Lingens. 1977. Abbau von Antipyrin durch Pyrazon-abbauende Bakterien. Z. Naturforsch. 32:557-562.

39. Schmitt, S., R. Müller, and F. Lingens. 1984. Chloridazon-catechol dioxygenases, a distinct group of meta-cleaving enzymes. Hoppe Seyler's Z. Physiol. Chem. 365:143-150.

40. Tittmann, U., W. Wegst, R. Blecher, and F. Lingens. 1980. Abbau von trans-Zimtsäure durch Chloridazon-abbauende Bakterien. Zentralbl. Bakteriol. Parasitenkd. Infektionskr. Hyg. Abt. 1 Orig. Reihe C 1:124-131.

41. Vandenbergh, P. A., R. E. Bawdon, and R. S. Berk. 1979. Rapid test for determining the intracellular rhodanese activity of various bacteria. Int. J. Syst. Bacteriol. 29:339-344.

42. Wegst, W., U. Tittmann, J. Eberspächer, and F. Lingens. 1981. Bacterial conversion of phenylalanine and aromatic carboxylic acids into dihydrodiols. Biochem. J. 194:679-684.

43. Weisshaar, R., and F. Lingens. 1983. The lipopolysaccharide of a chloridazon-degrading bacterium. Eur. J. Biochem. 137:155-161.

44. Weitzman, P. D. J. 1981. Unity and diversity in some bacterial citric acid-cycle enzymes. Adv. Microb. Physiol. 22:185-244.

45. Wilkinson, S. G., and D. P. Taylor. 1978. Occurrence of 2,3-diamino-2,3-dideoxy-D-glucose in lipid A from lipopolysaccharide of Pseudomonas diminuta. J. Gen. Microbiol. 109:367-370. 